\title{
O BRASIL: UM ESTADO-NAÇÃO A SER CONSTRUÍDO. O PAPEL DOS SÍMBOLOS NACIONAIS, DO IMPÉRIO À REPÚBLICA*
}

Joseph Jurt

Os símbolos nacionais revelaram-se necessários desde a constituição dos Estados-nação, no último quartel do século XVIII. A partir de então, os Estados não mais se definiram por meio de uma dinastia. Os novos Estadosnação, obrigados a criar um sentimento de pertencimento, serviram-se de toda uma série de instrumentos com esta finalidade. Anne-Marie Thiesse elaborou uma lista dos elementos utilizados visando à criação de identidades nacionais: "uma história estabelecendo a continuidade com os grandes ancestrais, uma série de heróis emblemáticos das virtudes nacionais, uma língua, monumentos culturais, um folclore, lugares simbólicos e uma paisagem típica, uma mentalidade particular" e, por fim, a autora cita "representações oficiais: o hino e a bandeira" (1999:14). Aos símbolos nacionais cabe uma função central, uma vez que visualizam de modo marcante os valores e os conteúdos da autodefinição política de uma comunidade, através dos quais os cidadãos conhecem e reconhecem sua identidade política. Por intermédio destes símbolos onipresentes e facilmente identificáveis, "formam-se as almas", para retomar uma expressão do historiador brasileiro José Murilo de Carvalho (1990).

\section{O simbolismo político: das monarquias às repúblicas}

Por ocasião de um colóquio em Genebra que versava sobre "o simbólico e a formação das identidades nacionais" (Jurt 1993), ${ }^{1}$ dediquei-me aos possíveis símbolos da nova Alemanha após a unificação dos dois Estados alemães. Em seguida, comparei os símbolos nacionais tradicionais da França e da Alemanha (Jurt 1999, 2000). Constatei, em primeiro lugar que, nas monarquias da Idade Média, o rei representava a permanência da comunidade nacional, como Ernst H. Kantorowicz (1992) demonstrou, 
com pertinência, em sua obra The king's two bodies. Nesta teoria dos dois corpos do rei, distinguia-se entre o corpo natural e o corpo político do rei. O primeiro era considerado submisso às leis biológicas — indo da infância à velhice e, por fim, à morte - ao passo que o corpo político era invisível e onipresente. Segundo este autor, transpusera-se a ideia teológica do corpus Christi mysticum como imagem da comunidade de crentes do Estado, considerado desde o século XVIII como corpus rei publicae mysticum, e reivindicando, tal como a Igreja, uma continuidade e uma imortalidade. O rei como cabeça desta comunidade encarnava tal continuidade enquanto corpo político. A coroa simbolizava a instituição e não somente a pessoa do rei. A máxima "O rei não morre jamais" era conhecida na França desde o século XVI e fora traduzida em medalhas por meio da imagem da fênix que ressuscita das cinzas.

Em seu estudo, Kantorowicz aspirava apreender a primeira fase do Estado soberano e sua pretensão à permanência. Ao fim desta evolução, encontra-se um poder sem corpo: o Estado como corporação. Segundo este autor, este fenômeno tem início com a dissociação da pessoa e da função do monarca, através da máxima dos "dois corpos do rei": "Estado soberano, nação, democracia" - escreve Marcel Gauchet (1981:136137) - "seria portanto de um corpo que saem as formas modernas do mundo dos homens, formas dessubstancializadas, restos sutis, avatares desencarnados de uma carne real [...] O anonimato definitivo do poder democrático é função da possível identificação do conjunto social do poder". "O poder sem corpo" da República não podia, no entanto, abrir mão de uma representação visível de sua potência e do direito. Ao contrário, necessitava fortemente de símbolos coletivos, porque a nação não podia se reconhecer na pessoa do monarca que representava a permanência da comunidade política. Sendo assim, os soldados da Suíça republicana, que não podiam reivindicar os brasões de uma dinastia aristocrática, portavam como signo de reconhecimento uma cruz branca que remetia a São Maurício, chefe da legião tebaica que havia morrido como mártir. Esta imagem traduzia igualmente a autodefinição da Confederação Helvética como "povo eleito" (Capitani 1991).

A Confederação Helvética não foi a única república do período. É bastante significativo que tenha sido no contexto da insurreição dos Países Baixos - que pertenciam à Espanha - que tenham surgido, pela primeira vez, os símbolos nacionais em um sentido moderno: o Hino Nacional e a Bandeira Nacional. O canto comum devia traduzir e reforçar um sentimento comunitário. A bandeira tricolor vermelha-branca-azul, que havíamos visto pela primeira vez em 1572, se distinguia por sua simplicidade das bandeiras 
espanholas, bastante ricas, e encarnava os valores fundamentais dos Países Baixos em revolta - sobretudo a ideia da liberdade religiosa e política.

Os Países Baixos e a Confederação Helvética, como repúblicas, constituíam exceções à regra que era a monarquia, considerada a melhor forma de Estado. A grande cesura foi, no entanto, a Revolução Francesa, com a transferência da soberania da pessoa do rei à nação. O novo Estado soberano e a noção de cidadão deviam criar novos símbolos. O que caracterizou esta passagem foi o pathos de um início radical que também se traduziu na criação de um novo calendário que transformaria radicalmente o antigo ritmo temporal (Baczko 1992). Ao mesmo tempo, destruíam-se sistematicamente os símbolos do Antigo Regime. O Estado-nação moderno, oriundo da Revolução Francesa, havia criado novos símbolos: a bandeira tricolor, a Marselhesa e a figura da Liberdade como encarnação da República.

\section{A bandeira nacional na França e na Alemanha}

A bandeira tricolor francesa, que substituía a bandeira com as flores de lis da monarquia, foi dotada de um conteúdo político cujo alcance ia além da França. Sua origem seria militar. Lafayette, enquanto comandante da nova guarda nacional, teria buscado um signo de reconhecimento para as suas tropas e teria acrescentado ao branco da guarda francesa, o azul e o vermelho da milícia parisiense. O novo emblema foi "o testemunho de uma unidade restabelecida, um símbolo de aliança e de concórdia" (Girardet 1984:10). A bandeira tricolor teve sua verdadeira confirmação por ocasião da Festa da Federação, em 14 de julho de 1790, quando Lafayette prestou seu juramento diante do altar da pátria diante de uma multidão de tricolores. Escreveu Raoul Girardet:

Tudo se passa como se, neste momento decisivo da história da ideia da nação, esta última exigisse uma representação visual, um signo tangível de identidade e de reconhecimento. Consciente ou inconscientemente, ligado às vicissitudes do acontecimento, mas transcendendo-o, um novo culto comunitário se desenvolveu, reivindicando, como todos os cultos, seu ritual e suas imagens (Girardet 1984:13).

A bandeira tricolor se impôs, em seguida, como emblema nacional em todos os domínios e, em 1794, também como bandeira da Marinha. Por ocasião de um debate na Convenção, em fevereiro de 1794, Jean-Bon-Saint-André falou da bandeira tricolor como a "linguagem" ou a "gramática" da República, sublinhando com isto o significado político do símbolo: 
A bandeira é, para o marinheiro, não somente o sinal de união, o guia material que o conduz à vitória: ela é ainda sua gramática, sua linguagem, o meio pelo qual comunica e recebe a grandes distâncias ideias bastante complicadas. Será por meio de um vocabulário monárquico que os generais dos exércitos republicanos darão ordens republicanas? [...] Tudo muda à nossa volta, nossas leis, nossos costumes, nossos hábitos, e os signos mudam também (Fehrenbach 1971:312).

A bandeira tricolor, símbolo da Républica, tornou-se, em seguida, o modelo para muitos Estados-nações ao longo do século XIX: na Itália, na Bélgica, no México e na Romênia.

Apesar da mudança de regime com o primeiro Império, a bandeira tricolor foi mantida sob Napoleão, mesmo que a águia imperial ocupasse uma nova função. Na Restauração (1815-1830), a bandeira tricolor deveria ceder lugar à bandeira branca, símbolo da revolta dos chouans ${ }^{2}$ e dos exilados. A partir de 1830, a bandeira tricolor permaneceria como símbolo nacional, independentemente da forma monárquica ou republicana do Estado. A tricolor iria se impor diante da bandeira vermelha, que se tornara, a partir de 1830, o signo positivo da Revolução social. Louis Blanc havia visto na tricolor o signo da concessão e sustentava que a bandeira vermelha era o verdadeiro estandarte do povo. Lamartine sublinhava contra este argumento o alcance universal da bandeira tricolor: "A bandeira vermelha que os senhores nos trazem somente deu a volta no Champ de Mars, arrastada em meio ao sangue do povo, e a bandeira tricolor fez a volta ao mundo com o nome, a glória e a liberdade da pátria!" (Agulhon 1979:122). O governo provisório de fevereiro de 1848 optou pela tricolor, acrescentando na bandeira as palavras "República francesa, Liberdade, Igualdade, Fraternidade" — " três palavras que explicam o sentido mais amplo das doutrinas democráticas das quais esta bandeira é o símbolo, ao mesmo tempo em que estas cores dão continuidade às tradições" (Agulhon 1979:126).

A tricolor impôs-se assim, simultaneamente, à bandeira branca da Restauração e à vermelha da Commune, e passou a significar, da II República até os dias de hoje, a fidelidade aos princípios de 1789 e o sentido da República, opondo-se, ao mesmo tempo, à reação e a uma nova revolução social: "O emblema de três cores tende a aparecer como símbolo somente da Pátria, uma Pátria indiferente [...] às mutações sucessivas do poder que a governa e das instituições que a gerem" (Agulhon 1973:43).

E em relação à bandeira nacional alemã? A tricolor alemã (negra, vermelha, dourada) só foi unanimamente adotada após 1949, depois de longas controvérsias internas, ao passo que as três cores francesas, colocadas de 
lado durante a Restauração (1815-1830), a partir de 1789 se tornaram, de certo modo, o símbolo reservado à Pátria, exterior e superior aos governos e às instituições sucessivas. As cores alemãs têm sua origem nas lutas de liberação contra Napoleão (Hattenhauer 1984). Os estudantes que lutaram pela liberdade e pela unidade nacional as adotaram, a elas acrescentando, pela primeira vez, o ouro, que significava a luz da verdade, ao passo que o negro significava, segundo o poeta Ernst Moritz Arndt, a obscuridade do regime dos príncipes, que se desejava ultrapassada, o vermelho encarnando, por sua vez, o fervor da liberdade. Foi em 1848, após a Revolução de março, que as três cores se tornaram expressão institucional da liberdade política e que o Parlamento de Frankfurt as adotou oficialmente como bandeira nacional, embora esta tentativa tenha se traduzido em fracasso em 1850.

Apesar do proclamado desinteresse de Bismarck pela questão dos símbolos nacionais, o Império fundado em 1871 quis manter distância da tradição libertária do negro, vermelho e dourado, propondo o negro, o branco e o vermelho como nova bandeira que aliava as cores da Prússia (negro e branco) àquelas das cidades hanseáticas (branco e vermelho). Por ocasião da criação da República de Weimar, houve um debate muito intenso em torno das cores nacionais; aqueles que desejavam se vincular à tradição liberal da bandeira negra, vermelha e dourada do Parlamento de Frankfurt tiveram ganho de causa; mas os conservadores e os monarquistas, considerando esta escolha uma traição em relação ao passado da Alemanha unida, obtiveram a manutenção da bandeira do Reich para a Marinha. As intermináveis disputas em torno das duas bandeiras marcaram a instabilidade da República de Weimar.

Hitler compreendera bastante bem a importância dos símbolos para a consciência coletiva. Em 1923, concebera, ele próprio, a bandeira com a cruz suástica. Para satisfazer o meio nacional conservador, ele fingiu retomar as cores do Reich, das quais dispunha de outro modo. O fundo vermelho devia remeter à ideia social de movimento, o branco, ao nacionalismo e a cruz suástica, à vitória do homem ariano. A partir de 1935, o que foi a princípio um emblema do partido se tornou a bandeira nacional (Paul 1990). Após o período nazista, na Alemanha, houve uma grande desconfiança em relação aos símbolos nacionais.

Por ocasião da fundação da RFA, em 1949, houve um clamor unânime pela bandeira negra, vermelha e dourada, com a ideia de vínculo com a tradição da República de Weimar e com o Parlamento de Frankfurt. As cores eram definidas pelos valores unidade e liberdade, ou unidade na liberdade. De modo significativo, a RDA adotou, em 1949, as mesmas triplas cores, enfatizando assim a unidade, ao passo que os comunistas haviam clamado, 
em 1918, pela bandeira vermelha. Em 1959, a RDA procurou marcar ainda mais a sua diferença em relação à RFA, acrescentando à bandeira os brasões do Estado - o martelo e o compasso - uma coroa de espigas de centeio, emblema que era visivilmente uma variação a partir do martelo e da foice que ornavam a bandeira da URSS; as espigas ali também representando outra forma "popular" da coroa de louros. A partir de então, os encontros internacionais frequentemente originaram disputas em torno das bandeiras. Foi nos Jogos Olímpicos de Munique, em 1972, que a bandeira e o hino da RDA foram reconhecidos e admitidos ao lado dos símbolos da RFA.

Por ocasião das manifestações da segunda-feira em Leipzig, após a queda do Muro em 1989, vimos surgir cada vez mais bandeiras da Alemanha Ocidental - negra, vermelha e dourada, sem os brasões da Alemanha Oriental - ao mesmo tempo em que se observava que o slogan "Nós somos o povo" se transformara em "Nós somos um povo", expressão que marca uma reivindicação cada vez mais forte de unidade. Após 1990, a bandeira negra, vermelha e dourada tornou-se a bandeira da Alemanha unificada. Trata-se, contudo, de uma fraca simbolização. A bandeira, reduzida à sua função oficial sobre os monumentos, quase não é adotada de forma privada pela população, exceto por ocasião das grandes manifestações esportivas (por exemplo, na Copa do Mundo da Alemanha, em 2006).

As mudanças sucessivas de bandeira na Alemanha indicam certa descontinuidade do país. A permanência da bandeira tricolor francesa, que foi interpretada como uma fusão das cores da cidade de Paris e daquelas da monarquia, remete à estabilidade do sentimento nacional na França, que aparentemente repousa em um consenso que não foi questionado pelas mudanças da forma do Estado.

\section{O Hino Nacional na França e na Alemanha}

Do mesmo modo, a Marselhesa tornou-se uma expressão evidente da nação francesa, através da qual a nação se representa, ela própria, deixando de se dedicar ao elogio do monarca, como era o caso nos antigos hinos reais (Vovelle 1984). A Marselhesa marcou, a exemplo da bandeira tricolor, signos. A Marselhesa foi o primeiro hino nacional moderno. Segundo a lenda, o prefeito de Estrasburgo, o barão de Dietrich, teria pedido, na noite de 25 para 26 de abril de 1792, a Rouger de Lisle, servindo em Estrasburgo na ocasião, que escrevesse um canto de guerra, após a declaração de guerra à Áustria, em 20 de abril de 1792: "Até agora, nenhum canto patriótico despertou o entusiasmo tão necessário em tempos de guerra; poeta e músico como o senhor o é, capitão, cabe 
ao senhor escrever um hino para ser cantado em todas as ocasiões em que for preciso despertar a paixão patriótica" (Paquette 1992:243). O hino, composto por Rouget de Lisle, chamou-se, a princípio, "Canto de guerra para o exército do Rhin"; era um canto patriótico que enaltecia a pátria armada diante do inimigo. O canto não remete a um desaparecimento selvagem do inimigo, mas apela igualmente para a generosidade ("franceses em guerreiros magnânimos/ Desfiram ou retenham seus golpes"). A dimensão revolucionária manifesta-se na apoteose da liberdade que deve ser defendida contra a tirania.

Quatro dias após a sua redação, o canto foi executado pela Guarda Nacional na Place des Armes em Estrasburgo e, em junho, o tipógrafo local Dannbach distribuiu o texto aos soldados da guarnição. Em julho, voluntários, partindo de Marselha em direção a Paris, entoaram o canto por ocasião de sua travessia pela França, tornando-o público junto à população. No momento da entrada das tropas federadas marselhesas no Jardin des Tuileries, a multidão parisiense batizou o canto de a Marselhesa. Em 24 de novembro de 1793, a Convenção decidiu que o hino da liberdade deveria ser cantado por ocasião dos acontecimentos marcantes da República. Em 14 de julho de 1795, a Marselhesa foi declarada canto nacional, permanecendo ligada à memória da Revolução Francesa. É significativo, como observa Michel Vovelle (1984), que todos os regimes autoritários, desconfiando da ideia democrática, tenham proibido o hino, por exemplo, sob Napoleão e durante a Restauração. Em 1830, ela deu o sinal da Revolução. Sob Napoleão III, desapareceu uma segunda vez para se transformar não somente em hino nacional na III República, mas em expressão da emancipação dos povos em toda a Europa do século XX (Vovelle 1984:102).

O "canto dos alemães", composto por Heinrich Hoffman von Fallersleben, em 1841, Deutschland, Deutschland über alles, permaneceu particularmente controverso. O autor pretendia magnificar a unidade nacional para além dos particularismos provinciais. Em seguida, a letra foi reinterpretada em um sentido hegemônico como indício da pretensão da Alemanha em afirmar sua superioridade sobre as outras nações. Por esta razão, somente a terceira estrofe é cantada oficialmente, Einigkeit und Recht und Freiheit (Unidade e Direito e Liberdade), a melodia sendo aquela que havia sido composta em 1797 por Joseph Haydn para a Áustria. A RDA promulgou, a partir de sua fundação, em 1949, um hino nacional específico, Auferstanden aus Ruinen, concebido por Johannes Robert Becher sobre uma melodia composta por Hanns Eisler. O hino é um chamado ao futuro e à unidade alemã: Deutschland, einig Vaterland!, verso retomado pelo movimento da Alemanha Oriental em 1989. Desde os anos 60, e com a política de separação nacional, este apelo já não era conveniente e na RDA contentavam-se uni- 
camente em tocar a melodia. Por ocasião dos Jogos Olímpicos, só houve até 1964 - uma única equipe alemã. No lugar do hino, tocava-se então a Ode an die Freude, de Schiller, sobre a melodia de Beethoven.

Este "Hino à alegria" foi tocado particularmente por ocasião da cerimônia de unificação em Berlim, em 03 de outubro de 1990. L. Bernstein havia proposto uma nova versão que transformasse o "Hino à alegria" em "Hino à liberdade" (Freiheit, schöner Götterfunke). O hino à alegria remete à nação de cultura de dimensões universais e não exprime em nada uma identidade propriamente nacional. O hino alemão, apesar de uma bela melodia, permaneceu controverso e não constitui um símbolo nacional no sentido forte do termo (Hattenhauer 1984; Reichel 2005). A história dos símbolos nacionais nos dois grandes países vizinhos, França e Alemanha, apesar das similitudes (estruturais), está longe de ser idêntica. As diferenças se devem a uma evolução política muito dessemelhante, particularmente devido à constituição tardia da Alemanha como Estado-nação. Após este rápido sobrevoo sobre o simbolismo político na França e na Alemanha, tentemos observar a história dos símbolos nacionais do Brasil para apreender a presença de uma tradição europeia, para além dos elementos autenticamente nacionais que mais nos interessam atualmente.

\section{A realidade constitucional no Império do Brasil}

A República que, no Brasil, só se constitiu em 1889, teve de se dotar de novos símbolos políticos. Mas esta República não representou uma ruptura definitiva com o regime monárquico, imperial, anterior, o Império do Brasil, já que este último não era um "Antigo Regime"; ele se constituíra com a Independência do Brasil, em 1822. Armelle Enders (1997) mencionou, por esta razão, "um processo insólito de emancipação", e Bartolomé Bennassar e Richard Marin (2000), uma "emancipação atípica".

Logo após as Revoluções liberais no Porto e em Lisboa, em 1820, a Assembleia Constituinte portuguesa pretendeu pôr fim à dependência de Portugal em relação à corte do Rio e exigiu o retorno do rei D. João VI à metrópole, o que ele empreendeu em julho de 1821, ao mesmo tempo em que instituía seu primogênito, Dom Pedro, como seu herdeiro e regente do Reino para o Brasil. Portugal contava em administrar o conjunto novamente a partir da metrópole e anunciou o envio de tropas ao Brasil. Por aqui, temia-se um retorno ao antigo estatuto colonial e a perda da liberdade comercial, ainda mais tendo em vista que as cortes portuguesas exigiam também o retorno imediato de Dom Pedro, a quem não mais caberia a função de regente. 
D. Pedro, que tinha 10 anos por ocasião de sua chegada ao Brasil, em 1808, tinha se apegado a seu novo país e, em face da campanha em favor de sua permanência, respondeu, em 09 de janeiro de 1822, decididamente, "Fico". Quando soube, às margens do Ipiranga, ao sul de São Paulo, que as Cortes pretendiam pôr fim aos seus poderes, lançou, em 07 de setembro de 1822, o célebre "grito do Ipiranga": "Independência ou Morte!". Em $1^{\circ}$ de dezembro de 1823, ele foi coroado imperador do Brasil, sendo chamado de Pedro I. O reino do Brasil transformou-se assim em Império. A ideia imperial aliava-se à independência; ela parecia em condições de "conciliar o Antigo Regime e a Revolução, a continuidade dinástica com os Bragança e o advento de uma nova Nação" (Enders 1997:25). Através desta solução monárquica, evitava-se a crise de legitimidade com a qual se haviam deparado os novos governos da América hispânica.

A independência não se devia naturalmente à iniciativa exclusiva de Dom Pedro. Ela não emanava tampouco - como se verificou frequentemente na Europa - de um sentimento nacional que suscitava a ideia de pertencimento a uma nação comum. Patricio Nolasco (1997) enfatiza, por um lado, a importância do desejo de autonomia existente entre as elites provinciais. Por outro lado, um elemento complementar, que se produzia sobretudo na capital, teria tido um papel crucial na reunião de forças visando à independência:

A questão do retorno do rei a Portugal. O retorno da Corte a Lisboa, conjugado com a manutenção de uma forma de soberania portuguesa sobre o Brasil, teria sem dúvida afetado profundamente os grupos sociais que construíram sua existência em torno da Corte no Rio de Janeiro [...]. Era junto a estes grupos, formados por homens em geral nascidos no Brasil, que o desejo de independência, na unidade, era mais marcado (Nolasco 1997:114).

Trata-se aqui, segundo o próprio autor, do grupo de "servidores do Estado" no sentido mais amplo, cuja homogeneidade do recrutamento pôde atenuar as clivagens. ${ }^{3}$

Outros fatores puderam favorecer a independência. Por trás da fachada unitária perfilava-se a autonomia das diferentes províncias, que parecia ser mais bem garantida pelo Rio do que pelo governo português. O principal ponto comum às diferentes regiões brasileiras era a estratificação social profundamente desigual que repousava sobre a escravidão. Patricio Nolasco se pergunta se a escravidão, apesar da exclusão que inflinge, não teria sido "um dos pilares da unidade brasileira que se pretende nacional" (Nolasco 1997:110): 
A independência e a unidade brasileiras sob a soberania de um imperador, filho do rei de Portugal, apareciam menos como o despertar de uma consciência nacional uniformemente compartilhada do que como um compromisso entre os desejos de autonomia e de estabilidade das províncias - mais exatamente daqueles que as dominam — temendo antes de tudo que a ordem seja perturbada (Nolasco 1997:110).

Um dos suportes do movimento independentista havia sido a camada social dos grandes proprietários, que aspirava obter a independência mantendo as estruturas sociais e econômicas existentes. A pessoa do monarca funcionava como símbolo de identificação e como garantia da estabilidade social (Bernecker et alli 2000:127). Ostentando seus vínculos com as dinastias europeias e seu estatuto de única monarquia americana, "aliada à 'política europeia' contra a 'política americana' republicana - a estratégia de Pedro I [e de seu sucessor] consistia em tergiversar diante das pressões britânicas [que demandavam a abolição da escravatura] para figurar para as oligarquias regionais como sua mandatária privilegiada junto às demais monarquias europeias" (Alencastro 2006:369).

Durante o período da Assembleia Constituinte, em 1823 e, mais tarde, no Parlamento, esboçaram-se no Brasil três correntes políticas importantes: primeiro, os exaltados, que adotaram uma atitude bastante crítica em relação ao imperador e à monarquia, sem constituir, no entanto, um grupo de grande importância. Os governos foram dirigidos ora pelos moderados (ou liberais), ora pelos conservadores, que se alternavam no poder. Os primeiros aprovavam a monarquia, mas aspiravam limitar as prerrogativas do monarca através de um quadro constitucional; os conservadores, por sua vez, aprovavam sem hesitação o conjunto das prerrogativas do imperador, prerrogativas estas que ele havia definido por meio da Carta "outorgada" em 1824 (Rumpf 2004:24).

Se o pensamento político no Império do Brasil inspirava-se fortemente no modelo britânico de monarquia constitucional, ao imperador era acordada, no entanto, uma função preeminente. O texto da Carta era influenciado pelo conceito de "Poder moderador", contido nos Princípios Políticos que Benjamin Constant havia redigido para Napoleão durante o "governo dos 100 dias". ${ }^{4} \mathrm{O}$ "poder real" é aí definido como um poder neutro, como árbitro dos demais poderes, devendo velar pelo equilíbrio destes últimos (Benjamin Constant 1997). Esta função de controle constituía de fato um quarto poder ao lado dos três poderes clássicos. O imperador podia nomear os senadores; ele dispunha do direito de dissolver a Assembleia, bem como do direito de nominação aos cargos públicos. 
A nação juridicamente criada pela Constituição de 1824 só se exprimia por uma pequena parcela de seus cidadãos, aos quais se reconhecia o direito de eleger e de ser eleito, tendo em vista sua situação social e financeira. A nação excluía a grande maioria dos habitantes do Brasil, a saber, os escravos; em outros termos, mais da metade da população brasileira (Nolasco 1997:109).

Em 1831, diante da oposição crescente contra seu ministério demasiado lusófilo, Dom Pedro I abdicou, retomando o trono de Portugal, e fez com que seu filho Pedro, nascido em 1825, fosse proclamado imperador do Brasil. Como este último tinha somente 5 anos na ocasião, o poder foi confiado inicialmente a uma tríade de Regentes. Pedro II reinaria a partir de 1840, por 49 anos, explorando plenamente as prerrogativas que lhe acordava a Carta de $1824 .^{5}$

A posição dos partidos dominantes não era marcada somente por sua atitude diante das prerrogativas do imperador, mas igualmente por sua posição em relação ao Estado Central. As vertentes tradicionais do setor econômico (os latifundiários e os comerciantes voltados para a exportação), bem como a alta administração eram a favor da concepção "centralista" do Estado defendida pelos conservadores. A agricultura orientada para o consumo local, bem como os produtores de café das provícias de São Paulo e de Minas Gerais advogavam antes pela autonomia regional, visando promover seus interesses. Por esta razão, eles se sentiam mais próximos do Partido Liberal; os intelectuais das profissões liberais e a classe média das cidades optavam igualmente pelos liberais, uma vez que estes defendiam as liberdades individuais (Rumpf 2004:29-30). Os dois campos, em luta contínua, forjaram, todavia, entre 1853 e 1862, uma coalisão no interior da qual os conservadores davam o tom.

\section{O simbolismo político do Império do Brasil}

Desde 1815, o Brasil não possuía um estatuto colonial e, em 1822, atingiu sua indepêndencia completa, reconhecida em 1825 por Portugal. O país constituía-se assim como um novo Estado-nação. Tendo em vista a ausência de uma consciência nacional amplamente difundida, a referência à nação ligava-se estritamente à criação do Estado. Nesse contexto, as elites políticas tinham o maior interesse em construir uma ordem simbólica apta a exprimir uma identidade nacional.

Sob o regime de Napoleão, Joachim Lebreton (1760-1819) havia se tornado primeiro secretário da Academia de Belas Artes de Paris. Após a queda 
definitiva de Napoleão, em 1815, Lebreton, como muitos outros membros da Academia, em geral bonapartistas, não se sentia mais seguro na França da Restauração. Sendo assim, também ofereceu seus serviços ao príncipe regente Dom João, no Rio de Janeiro.

No início de 1816, chegou ao Brasil um grupo relativamente numeroso de antigos membros da Academia de Belas Artes; entre eles figurava, é claro, Joachim Lebreton; o pintor de história, Jean Baptiste Debret (1768-1848); o pintor de paisagens e de batalhas, Nicolas-Antoine Taunay (1755-1830); o arquiteto Auguste Grandjean de Montigny (1776-1830); o escultor Auguste-Marie Taunay (1768-1824), para nomear somente os mais importantes. A atividade deste grupo, que entrou para a história sob a denominação de Missão Artística Francesa, teve um papel bastante relevante na nova vida cultural brasileira. O grupo introduziu o estilo neoclássico em um Brasil marcado até então pelo barroco colonial. ${ }^{6}$ Se após 1815 a influência econômica da Grã-Bretanha era predominante, ela seria em certa medida compensada pela atividade cultural dos franceses. Em agosto de 1816, Dom João VI assinaria o decreto criando a Escola Real de Ciências, Artes e Ofícios, no interior da qual os franceses atuaram de forma significativa. A missão francesa marcou, assim, o estilo dos grandes acontecimentos dinásticos no Rio: a entronização de Dom João VI (1817), a chegada da arquiduquesa Leopoldina, da casa dos Habsburgo, futura esposa de Pedro I, bem como a coroação de Pedro I como imperador do Brasil independente. ${ }^{7}$

O pintor Jean-Baptiste Debret, sobrinho e aluno de David, ficou encarregado de organizar a Academia de pintura e, estando em contato com Pedro I antes de sua coroação, tornou-se um dos pintores preferidos da Coroa imperial. ${ }^{8}$ Pedro I encarregou-o de desenhar uma bandeira para o Império independente do Brasil, destinada a se tornar o símbolo da nação em vias de constituição. A bandeira proposta por Debret era composta de um retângulo verde, no centro do qual figurava um losango amarelo. $\mathrm{O}$ verde correspondia à cor da dinastia de Pedro, a família real dos Bragança, e o amarelo, à dinastia da qual era oriunda sua mulher, os Habsburgo [Figura 1]. A bandeira mantinha, portanto, a tradição dinástica e não significava (ainda) o verde das florestas amazônicas nem o ouro do subsolo, como se reinterpretaria mais tarde. ${ }^{9}$

A forma losangular remetia, aliás, às bandeiras dos regimentos do exército napoleônico, como se pode ver, por exemplo, no quadro de David Le Serment de l'armée fait à l'Empereur après la distribution des Aigles au Champ de Mars le 5 décembre $1804 .{ }^{10}$ Sobre o losango amarelo encontrase um brasão azul com a esfera armilar sobre uma cruz (vermelha) da ordem de Cristo, envolta por um anel azul carregado com 20 estrelas de prata, e 
Figura 1 - Esboço da bandeira do Império brasileiro, por Jean-Baptiste Debret

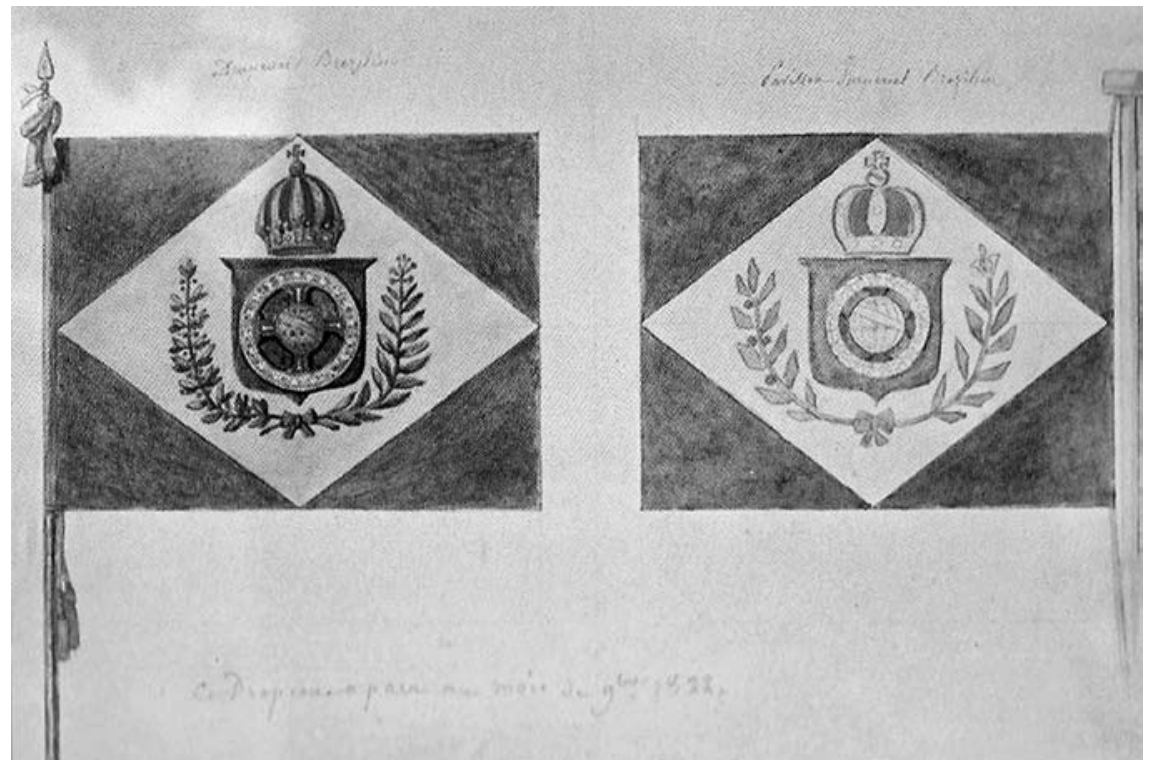

circundando a cruz, dois ramos (um de café, o outro de tabaco). A esfera armilar (representando a esfera celeste local), também conhecida como "astrolábio esférico", encontrava-se desde 1645 na bandeira do Principado do Brasil. O brasão e a forma típica da coroa imperial remetiam à tradição portuguesa. As 20 estrelas, por outro lado, referiam-se às 20 províncias do Brasil, enquanto os dois ramos anteriormente citados evocavam a realidade agrícola brasileira. A Bandeira do Brasil distingue-se, assim, a partir de sua independência, por seu perfil específico: as duas cores, verde e amarelo, e a forma losangular. Não haverá mudanças em sua estrutura de base.

A história do Hino Nacional não oferece a mesma continuidade. O imperador Pedro I havia composto, ele próprio, a música de um hino, sobre letra de Evaristo da Veiga, com o título Hino constitucional Brasiliense que, em 1822, seria denominado Hino da Independência do Brasil. Após a abdicação de Pedro I (1831), este hino foi abandonado.

Um dos compositores brasileiros mais conhecidos, Francisco Manuel da Silva, aluno do compositor Sigismund Neukomm (este último, aliás, aluno de Haydn e um dos membros da Missão Artística Francesa), havia proposto, desde 1822, um outro hino, com letra de Ovídio Saraiva de Carvalho e Silva. Este hino, uma marcha patriótica composta ao estilo do romantismo italiano, conheceria rapidamente grande popularidade. Após a partida de Pedro I, ele 
Figura 2 - Bandeira Imperial, 1822

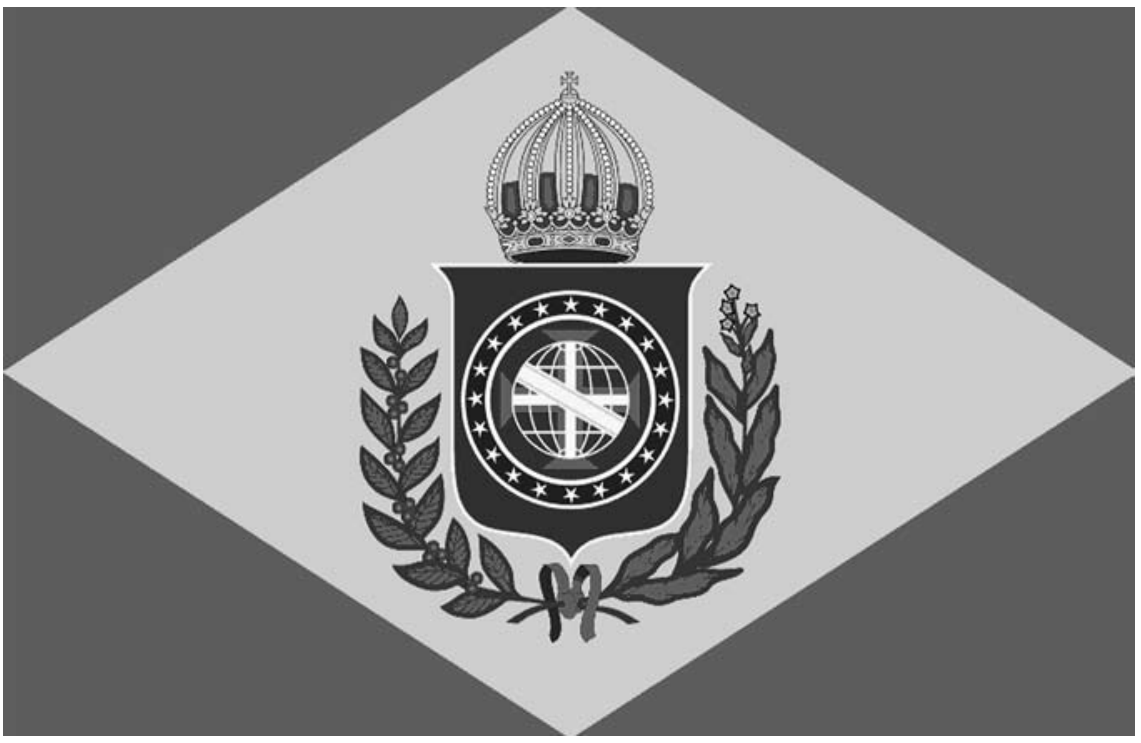

não mais seria chamado de Hino Nacional, mas de Hino do 7 de abril [1831], em referência ao dia da abdicação de Pedro I, ou simplesmente Marcha Triunfal. Na regência de Pedro II, este novo hino foi tocado por ocasião de acontecimentos solenes, mas sem a letra, julgada demasiado hostil a Pedro I e a Portugal. Sua melodia contagiante, por outro lado, permaneceria muito popular, para além do regime imperial, como veremos.

\section{A abolição do tráfico, a imigração e o nascimento de um "nacionalismo de Estado"}

O período do Império foi relativamente limitado no que diz respeito a símbolos, já que o imperador era, ele próprio, enquanto garantia da unidade nacional, seu símbolo mais importante. No entanto, esta unidade era ameaçada por conta das grandes desigualdades sociais e da manutenção do sistema escravagista. O reconhecimento inglês da independência do Brasil foi condicionado pelo respeito ao embargo do tráfico de escravos. O Brasil contemporizou, ao avançar que uma interrupção "precipitada" da importação de escravos colocaria em perigo a própria existência do Estado do Brasil (Alencastro 2006:366). Em 1831, o Brasil adotou uma lei que deveria reprimir o tráfico de escravos, mas ela não foi aplicada. 
O governo britânico voltaria à carga, agora com maior firmeza. De acordo com a lei Aberdeen, os traficantes, comparados a piratas, foram perseguidos até mesmo nos portos brasileiros e trazidos diante dos tribunais da Marinha britânica. Neste contexto, o ministro do Império, Eusébio de Queirós, descendente de uma família portuguesa de Angola, fez com que o Parlamento adotasse, em 4 de setembro de 1850, uma lei proibindo definitivamente o tráfico. Os africanos capturados pelas autoridades tornariam-se "escravos da nação" e seriam colocados sob a tutela do Estado (Enders 1997:47). Luiz Felipe de Alencastro designou esta proibição irreversível do tráfico como um "segundo nascimento do Estado brasileiro" (2006:373) e explicou esta mudança de atitude do seguinte modo:

A comparação, pelo Bill Aberdeen, do tráfico brasileiro à pirataria rebaixava o Império ao nível das "nações bárbaras", o que dava contornos concretos à ameaça de intervenção britânica. Este deslize categorial desacreditava os valores civilizatórios que a monarquia dos Bragança pretendia assegurar ao país. A dupla atribuição da Coroa - poder central no espaço nacional e mandatária das oligarquias regionais junto às coroas europeias - era atingida em sua consubstancialidade política (Alencastro 2006:373).

Em complemento à economia escravagista, houve desde os anos 1820 uma imigração europeia; terras públicas foram distribuídas a colonos europeus nas zonas ameaçadas por tribos indígenas ou por quilombolas (Alencastro 2006:377). O rei Dom João VI já não acreditava na exploração das minas de ouro, e sim nas promessas da agricultura. Sabendo que o sistema escravagista estava condenado a longo prazo, ele desejava homens livres para povoar suas terras. Na Suíça devastada pela fome, o diplomata friburguense Sébastien-Nicolas Gachet foi encarregado de negociar no Rio de Janeiro uma imigração de suíços para o Brasil (Nicoulin 1973). A partir de maio de 1818, o rei Dom João VI ratificou o tratado de colonização com os suíços, oferecendo-lhes terras nas regiões mais altas do Morro Queimado, na região do Rio de Janeiro, com condições vantajosas (supressão de impostos durante 10 anos e subvenções).

Mais de 2 mil pessoas, das quais 830 friburguenses, emigraram em direção à futura colônia suíça do Brasil e, em 3 de janeiro de 1820, o rei decretou oficialmente a fundação da cidade denominada Nova Friburgo; os colonos começaram, a partir de então, a explorar as terras, mas os resultados foram decepcionantes, somente uma economia de subsistência tendo sido alcançada. Se a partir de 1824 colonos alemães instalaram-se igualmente em Nova Friburgo, grande parte dos suíços deixou suas terras ingratas para 
se engajar como soldados ou contramestres nas fazendas. A maioria dos colonos suíços cultivaria café nas terras de Macaé e praticaria a escravidão como seus contemporâneos brasileiros.

Tendo em vista que, a partir da abolição da escravatura, os fazendeiros desejavam contar com uma mão de obra que pudesse substituir os escravos, a administração imperial, a intelligentsia e parte da população urbana, "preocupadas com a composição social e cultural da nação", "procuravam fazer da imigração um instrumento da 'civilização', dito de outro modo, de embranquecimento do país" (Alencastro 2006:377). ${ }^{11}$ Se os escravos haviam sido simplesmente excluídos da nação, os imigrantes, por sua vez, tampouco contribuíram para uma homogeneização étnica e cultural do país.

\begin{abstract}
Forjada pela escravidão, em seguida pela chegada de imigrantes europeus e asiáticos, suas disparidades culturais conduzem as classes dirigentes a se unirem em um "nacionalismo de Estado", cujo corolário é a reconstrução da sociedade: já que a organização do trabalho nos latifúndios incorpora continuamente estrangeiros, desestruturando o corpus social, os altos funcionários, os letrados, os intendentes - a intelligentsia estatal e paraestatal [...] — se advogam a missão histórica de civilizar a nação (Alencastro 2006:382).
\end{abstract}

Essa elite estava convencida de que era em primeiro lugar pelas estruturas estatais que se poderia construir certa unidade da nação, daí também a importância dos símbolos do Estado, que deveriam exprimir esta unidade ou, antes, contribuir para criá-la .

Mas outro grupo social deveria ter um papel importante neste contexto, a saber, o Exército, particularmente após a guerra da Tríplice Aliança entre Brasil, Argentina e Uruguai (1865-1870), uma guerra sem trégua que conduziu a perdas enormes do lado paraguaio (que perdeu $2 / 3$ de sua população). Durante esta guerra, todos os projetos de reforma que o imperador havia esboçado foram adiados, e os liberais reforçaram sua oposição ao regime. A Guerra do Paraguai suscitou, no entanto, modificações importantes na sociedade brasileira. Desde a criação da Guarda Nacional, em 1831, até a guerra em questão, o Exército havia ocupado uma posição marginal na sociedade brasileira (Enders 1997:54), que mudaria com a guerra mediante a criação de um espírito de corpo militar até então inexistente no Brasil (Benassar 2000:246).

Em A espada de Dâmocles, Wilma Peres da Costa (1996) enfatiza que a frustração dos oficiais militares era alimentada por sua oposição à Guarda Nacional, que assegurava milícias armadas a mando das elites agrárias e de senhores de escravos. O espírito de corpo do Exército, única corporação, ao lado da dos padres católicos, estruturada ao longo de todo o território, 
também visava assegurar a monopolização dos instrumentos de violência legítima. ${ }^{12}$ Havia algumas grandes famílias de militares, como o clã dos Fonseca, mas a instituição se abriu, a partir de então, a camadas sociais mais modestas. Se nos anos 20/30, boa parte dos estudantes de escolas militares era oriunda das elites agrárias ameaçadas de declínio, os oficiais provinham agora frequentemente de uma pequena burguesia urbana que desconfiava dos profissionais da política. Além disso, entre as tropas, houve escravos libertos graças ao serviço militar.

Em seguida à Guerra do Paraguai, o Exército adquiriu um lugar importante na sociedade. Com sua situação particular e seu sentimento de ser dotado de uma vocação messiânica em relação à nação, ele se tornou um fator decisivo. O Exército apresentou-se e considerou-se a partir de então como garantia da integridade nacional, assim como uma instituição no seio da qual os brasileiros estavam presentes independentemente de sua origem etnocultural (Bernecker 2000:165) ${ }^{13}$ Patricio Nolasco enfatiza, por sua vez, a importância do Exército para o processo de constituição de um sentimento nacional. A Escola Militar permitia uma ascensão social. "Um corpo relativamente homogêneo - em todo caso, no nível dos oficiais - e unido se constituiu, portanto, sobre bases 'nacionais', moldado pela experiência amplamente partilhada da guerra contra o Paraguai" (Nolasco 1997:115).

No entanto, o Exército estava longe de ser uma unidade coerente. No interior da instituição, duas facções se desenvolveram. Havia, por um lado, os militares tradicionais que se formaram na prática cotidiana do próprio Exército e, por outro, os jovens oficiais, oriundos da Academia Militar da Praia Vermelha do Rio, que se definiam pelo paradigma da ciência e designavam sua Academia de "tabernáculo da ciência" (Bruno 2003:239-240). Naquela instituição se ensinava tanto filosofia e matemática quanto estratégia militar. A formação das escolas militares privilegiava as matérias científicas, sobretudo a matemática, e a carreira de engenheiro era ligada à de oficial militar. Assim, a "juventude militar" estava enraizada em um tipo de formação que parecia se opor fortemente aos "estudos literários" dos bacharéis das escolas de direito, escolas nas quais era formada a maior parte da elite política. ${ }^{14}$

\section{Concepções variadas da República, positivistas, liberais ou jacobinos}

A "mocidade militar" defendia, em sua maioria, as ideias republicanas e positivistas. Para os oficiais, a República parecia ser o regime mais apropriado para satisfazer suas aspirações. O verdadeiro mestre da jovem geração 
militar era Benjamin Constant Botelho de Magalhães (1836-1891), professor de matemática e diretor da Escola Militar desde 1872, após ter exercido o comando enquanto engenheiro, por ocasião da Guerra do Paraguai. Profundo conhecedor da filosofia positivista de Auguste Comte, ele havia fundado, em 1876, a Sociedade Positivista do Brasil e iniciava futuros oficiais nessas novas ideias.

O governo, tendo elaborado em 1833 uma lei que parecia lesar seus interesses, as "velhas barbas" da Guerra do Paraguai e os jovens emulados de Benjamin Constant (assim eram nomeados resumidamente) se aliaram, e a tal "questão militar" começou a ocupar a cena (Enders 1997:55). Deodoro da Fonseca (1827-1892), veterano da Guerra do Paraguai, e Benjamin Constant fundaram então o Clube Militar. Esta aliança das duas tendências do Exército constituiu uma primeira etapa em direção à Proclamação da República. Os positivistas opunham-se à monarquia porque ela derivava, segundo a teoria dos três estágios de Auguste Comte, do estágio teológico, enquanto a República era considerada a forma do Estado da terceira fase, a fase positivista. Por ocasião da formação dos jovens oficiais, o centro de interesse era a formação técnico-científica, ao passo que a escola civil estava mais focada em uma formação literária. Por esta razão, a escola militar sentia-se próxima da ideia comtiana de uma "ditadura republicana" que deveria trabalhar em favor do desenvolvimento industrial do Brasil (Carvalho 1990:27-29). O positivismo recebeu grande número de adesões proveniente não somente dos meios da "juventude militar", mas igualmente das províncias no sul do país, do Rio de Janeiro até o Rio Grande do Sul, das classes médias, das universidades e das Academias.

Para além disso, na sociedade civil, duas correntes estavam igualmente próximas da ideia republicana. Por um lado, havia a oligarquia dos plantadores de café do estado de São Paulo, que não percebia que seus interesses estivessem sendo salvaguardados pelo Estado Central. Os plantadores defendiam uma estrutura federal para o Brasil. Sua filosofia era a de um liberalismo econômico: o bem público sendo considerado como a soma dos bens particulares. Este grupo inspirava-se no modelo dos Estados Unidos, mas esquecia que a sociedade colonial da América do Norte era muito mais igualitária, ao passo que seu ideal "republicano" de plantadores de café consistia em cimentar uma sociedade extremamente desigual. Entre os membros do Partido Republicano Paulista, fundado em 1873, a maioria era composta por grandes proprietários (Carvalho 1990:24-25).

No entanto, o republicanismo manifestou-se em primeiro lugar na capital, por meio do Partido Republicano que ali lançara seu manifesto em 1870. Os membros desta corrente do Rio de Janeiro eram recrutados entre 
as profissões liberais e a imprensa. Eles se inspiravam no conceito jacobino de República, promovendo princípios (que permaneceram relativamente abstratos) de igualdade e de liberdade. O Estado forte era para eles o instrumento decisivo para realizar seus objetivos políticos. Este grupo, relativamente restrito, era o único a vislumbrar a participação do povo nos negócios políticos (Carvalho 1990:25-26).

\section{A guerra dos símbolos na República proclamada}

O Império foi derrubado na madrugada do dia 15 de novembro de 1889 por um golpe, obra sobretudo de um grupo de militares, que não era particularmente republicano, mas pretendia defender seus interesses corporativos em face do governo; ele lançou sua ação em comum com os republicanos oligárquicos de São Paulo, hostis à monarquia por conta da abolição da escravatura (decretada em 1888). Entre os conspiradores também se encontrava Benjamin Constant, o ídolo dos quadros positivistas da Escola militar, bem como o advogado baiano Rui Barbosa, que havia passado do abolicionismo ao federalismo.

O personagem mais importante, ao menos do ponto de vista estratégico, era o chefe do Estado-Maior do Exército, o marechal Manuel Deodoro da Fonseca, que pretendia sobretudo impedir que seu inimigo, Gaspar Silveira Martins - político que havia sido ministro do Comércio por um breve período, a partir de 1880, senador e, por fim, conselheiro de Estado, defendendo uma monarquia parlamentar - fosse nomeado chefe do governo. Na aurora do dia 15 de novembro, Deodoro da Fonseca invadiu a sala do conselho de ministros juntamente com seus soldados e obrigou o gabinete a demissionar. Cedendo à pressão dos republicanos, o marechal proclamou a "República dos Estados Unidos do Brasil", do alto do balcão do Conselho Municipal do Rio, enquanto a multidão entoava A Marselhesa. Um oficial assinalou ao imperador que o governo provisório esperava que ele e sua família deixassem o solo brasileiro o mais cedo possível. Em 17 de novembro, o imperador partiu em direção ao exílio, primeiro em Portugal e em seguida em Paris, onde morreu em 1891.

Um pintor anônimo da Bahia representou a partida da família imperial pela manhã. Em primeiro plano, percebe-se o marechal Deodoro da Fonseca, que entrega a bandeira nacional a uma alegoria da República, trajada com um vestido branco e uma capa vermelha, sobre a qual a mão da Providência segura o barrete frígio (branco e não vermelho), enquanto a família imperial embarca em um navio. Este quadro, concebido em 1889, representa bem a idealização e a mitificação do que foi, na verdade, um golpe de Estado. ${ }^{15}$ 
Figura 3 - Alegoria da República. Pintura anônima da Bahia, 1889

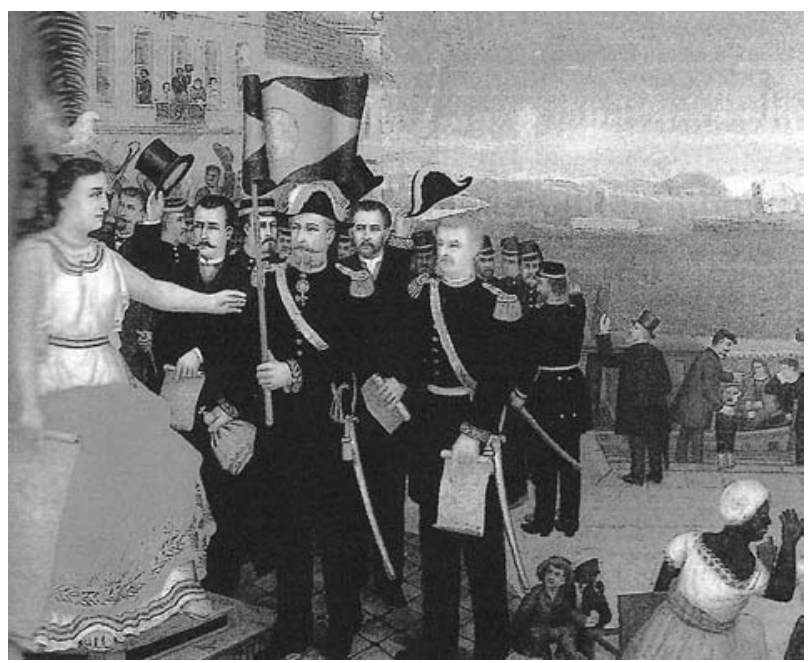

Surpreende, contudo, que o novo regime pudesse inspirar desde 1889 um pintor anônimo, que não pertencia aos meios do poder, na distante Bahia.

A República proclamada pelos republicanos de última hora, sem a participação direta do povo, devia exprimir sua legitimidade por meio de símbolos. Os símbolos oficiais essenciais seriam a bandeira e o hino, fixados em certo momento por decretos (Schwarcz 1999:109). Neste contexto, houve uma "guerra de símbolos", uma luta pela interpretação e pelo programa que se pretendia conferir à República proclamada. Os militares insurgentes do 15 de novembro não se alinhavam atrás de uma bandeira-símbolo. A Marselhesa havia sido um símbolo sonoro e verbal do qual o grupo republicano do Rio de Janeiro já tinha se servido anteriormente como emblema de seu entusiasmo republicano-revolucionário, interpretado como um hino universal e não nacional, o que não podia ser o caso para a bandeira tricolor (francesa). ${ }^{16}$ José Murilo de Carvalho observa que

[...] as bandas tocaram a Marselhesa e marchas militares sem despertar o entusiasmo da pequena multidão que se aglomerava em frente ao palácio. Estabeleceu-se um clima de expectativa. [...] Decidiu-se na hora que fosse tocado o hino [de Francisco Manuel da Silva] e que ele continuasse como hino nacional. As bandas militares, como se esperassem pelo resultado, irromperam com o popular Ta-ra-ta-ta-tchin, para delírio da assistência, segundo depoimentos de testemunhas oculares (Carvalho 1990:124-125). 
Figura 4 - Bandeira do Clube Republicano, 1889

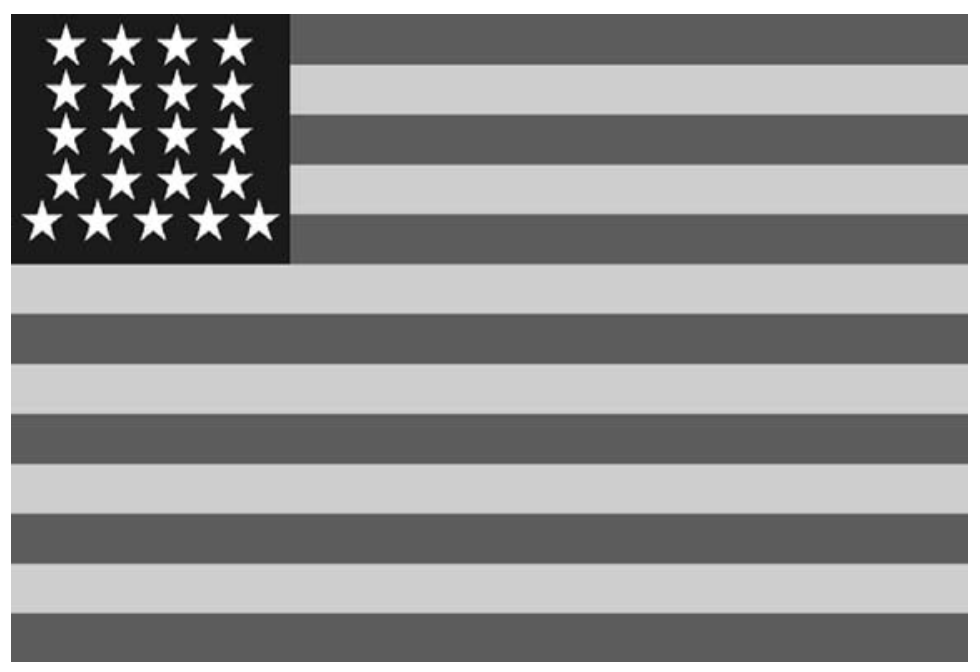

A partir da proclamação da República, surgiu uma nova bandeira dos Estados Unidos do Brasil: uma versão verde e amarela do Stars and Stripes norte-americano, com 20 estrelas sobre um quadrado negro. A bandeira, que mais tarde seria denominada "bandeira da Proclamação", flutuou ao menos até 19 de novembro no mastro de um edifício da Câmera Municipal do Rio de Janeiro (Carvalho 1990:111). O modelo dos republicanos do Rio havia sido a República francesa; mas tratava-se talvez de ganhar a simpatia dos liberais de São Paulo, que se inspiravam no modelo norte-americano.

Os positivistas, e particularmente Teixeira Mendes, da Igreja Positivista, se indignaram com esta bandeira tão pouco nacional. Eles encarregaram o pintor Décio Villares de desenhar um modelo alternativo a ser proposto, por intermédio de seu mestre Benjamin Constant, ao governo provisório. Os positivistas seguiram quase textualmente a concepção de Augusto Comte no que diz respeito à ideia da bandeira. A filosofia positivista do Estado entrava assim na simbologia política do Brasil. Aos olhos de Comte, o Ocidente encontrava-se em uma passagem "orgânica" do estágio metafísico em direção ao estágio industrial-científico. Comte concebeu a iconografia política correspondente a esta passagem. Ele propôs o que consta em seu Système de politique positive para a bandeira do Estado positivista do Ocidente, que deveria ultrapassar os Estados nacionais. Concebeu, em primeiro lugar, um estandarte religioso contendo "a fórmula sagrada dos positivistas: o amor por princípio, a ordem por base, e o progresso como objetivo" sobre um fundo 
verde, cor natural da esperança, própria aos emblemas do futuro" (Comte 1851:387) e, em seguida, a bandeira política: "A fórmula fundamental se decompõe, sobre as duas faces verdes, nos dois lemas que caracterizam o positivismo: um, político e científico 'Ordem e Progresso', o outro, moral e estético "Viver para o outro". ${ }^{17} \mathrm{O}$ modelo positivista resumido no lema "Ordem e Progresso" significava um novo começo nacional, uma última etapa da evolução civilizatória, e não uma ruptura revolucionária. ${ }^{18}$

No novo projeto de bandeira, realizado segundo as indicações do "apóstolo" positivista Teixeira Mendes, mantinha-se o fundo verde, o losango amarelo e a esfera azul no centro para significar a transição entre o passado e o presente, mas suprimia-se o que lembrava a dinastia reinante: a cruz da Ordem do Cristo, a esfera armilar, a coroa imperial, mas também os ramos de tabaco e de café, o progresso não residindo mais, segundo os positivistas, nas plantações de café e de tabaco, mas na indústria e na exploração dos recursos naturais.

Sobre a bandeira, no lugar dos símbolos monárquicos retirados, são propostos por Décio Villares uma esfera azul celeste coberta de estrelas e envolta por uma faixa com o lema (positivista) "Ordem e Progresso". As estrelas não estão dispostas seguindo uma ordem simétrica, como na bandeira dos Estados Unidos, mas representam exatamente a disposição das principais estrelas no céu do Rio em 15 de novembro de 1889, o dia da proclamação da República. Algumas estrelas foram aumentadas, outras reduzidas, mas foi sobretudo o signo marcado no meio da esfera que foi aumentado: o Cruzeiro do Sul, que havia servido aos portugueses e espanhóis, desde as primeiras grandes expedições, como ponto de orientação nos mares do hemisfério sul.

As estrelas não reproduziam somente a esfera estrelada no momento da proclamação da República, elas simbolizavam, ao mesmo tempo, os 20 estados do Brasil de acordo com seu tamanho e posição. A correspondência entre microcosmo (geográfico) e macrocosmo (celeste) vinha da filosofia de Auguste Comte, marcada por uma visão "orgânica" da história. As cores da nova bandeira eram, de fato, aquelas da Bandeira Imperial, mas reduzia-se a dimensão do losango, que não mais tocava o bordo exterior da bandeira. Apesar do novo desenho do símbolo central, surpreende a continuidade, antes de tudo, das cores. O Cruzeiro do Sul remetia à tradição dos navegadores portugueses. Esta ideia da continuidade correspondia igualmente à filosofia da história como evolução, noção cara a Augusto Comte. Ressaltemos que não se encontra, de fato, sobre a bandeira brasileira qualquer lembrança da simbologia política da Revolução francesa.

A bandeira republicana se liga à tradição anterior em termos simbólicos, mas a nova bandeira foi mais marcada pela filosofia positivista. Isto pode 


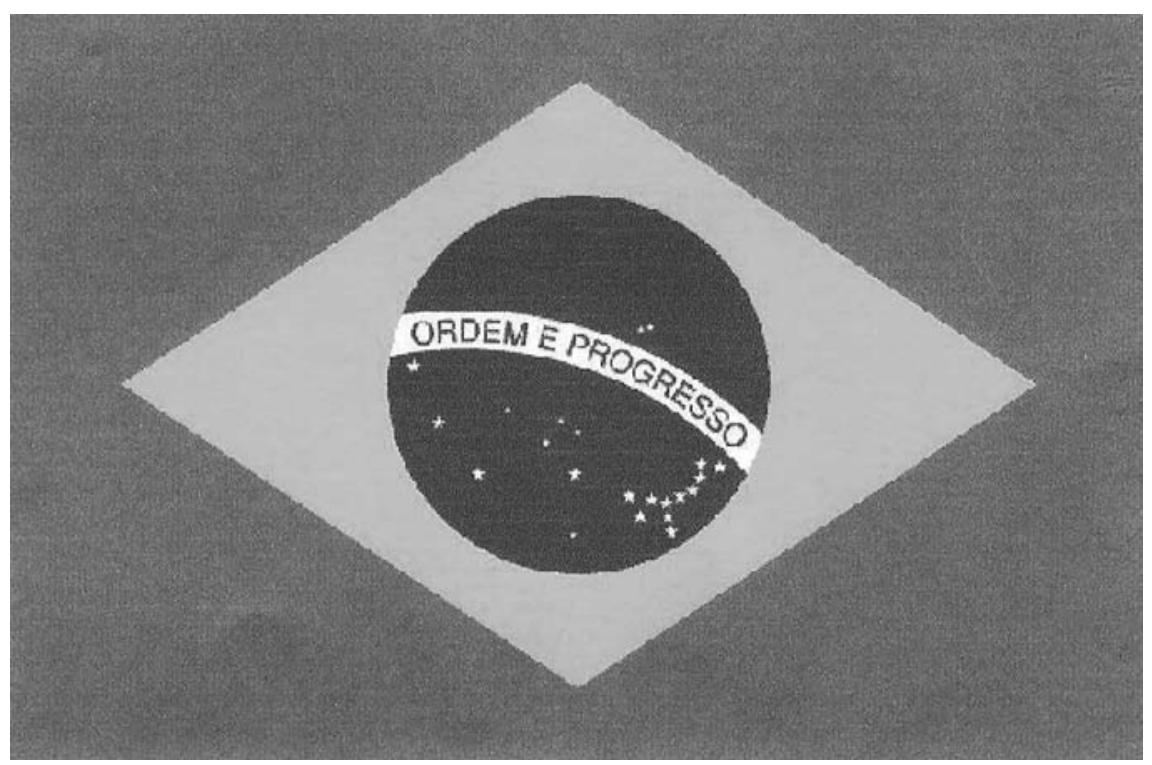

surpreender porque os positivistas não tinham tido um papel decisivo por ocasião da proclamação da República. Os oficiais alocados sob a égide de Deodoro da Fonseca somente defendiam esta nova forma de Estado para que ela restituísse ao Exército o papel que ele havia tido anteriormente "A República é a salvação do Exército": esta era a proposição de Deodoro da Fonseca às vésperas da Proclamação da República - uma legitimação mínima e, ao mesmo tempo, bastante particularista, corporativa, da nova forma do Estado (Carvalho 1990:40).

Para esta mudança de regime, inspirada por motivos contigentes, os positivistas dispunham, com seu conceito de evolução em três estágios, de uma "teoria" que permitia interpretar a mudança ocorrida. ${ }^{19}$ Apesar de muitas objeções, particularmente contra o lema "Ordem e Progresso", eles tinham conseguido impor sua interpretação no plano da simbologia política. O que surpreendia, no entanto, era que a nova Constituição do Brasil, datada de 1891, seguia antes o modelo dos Estados Unidos e não o conceito de "ditadura republicana" de Augusto Comte. ${ }^{20}$ Por esta razão, o Brasil era denominado República dos Estados Unidos do Brasil — uma denominação que se manteve até 1968, sendo substituída por "República Federativa do Brasil". A bandeira da República de 1889 permaneceu idêntica, apesar de várias mudanças de regime e de Constituição. A maioria dos cidadãos 
associava o lema "Ordem e Progresso" não tanto à ideia de uma "ditadura republicana", mas antes a um programa político e econômico que pretendia aliar um programa direitista de "Ordem"21 com a opção otimista do "Progresso". A Bandeira Brasileira tornou-se, desde 1889, o símbolo essencial do Brasil, seu "emblema".

Também é preciso mencionar, neste contexto, como bem lembrou Bernard Richard, as armas oficiais do Brasil. Reencontramos os ramos de tabaco e de café nos brasões oficiais da República brasileira, de um lado a outro de uma estrela de cinco pontas bordada de vermelho, cada ponta da estrela sendo metade verde, metade amarela; no centro da estrela há um escudo azul cercado por 20 (em seguida, 27) estrelas, tendo em seu centro a representação das cinco estrelas do Cruzeiro do Sul. Por fim, ao pé do brasão, o nome completo e oficial do país (República federativa do Brasil, segundo a titulação oficial, definitivamente adotada em $1^{\circ}$ de fevereiro de 1971) e a data da proclamação da República, 15 de novembro de 1889. Estes brasões republicanos, encomendados em 1889 pelo chefe do governo provisório, Deodoro da Fonseca, ao engenheiro Artur Zauer, derivam eles próprios do brasão criado em 1822, pouco tempo antes da proclamação da Independência, para o príncipe regente Dom Pedro, pelo pintor francês Jean-Baptiste Debret, já mencionado a propósito da bandeira. Logo em seguida, o brasão imperial de Pedro I, e depois de Pedro II, seria ao mesmo tempo aquele do Estado, do Império do Brasil. ${ }^{22}$

O segundo símbolo oficial importante é o hino, mais do que os brasões. Já dissemos que o hino imperial de 1831 (Hino do 7 de abril ou Marcha Triunfal) havia sido muito popular. No pequeno círculo dos republicanos do Rio, a Marselhesa tinha a mesma qualidade; ela fora cantada, como vimos, no dia da proclamação da República.

O governo provisório promoveu, em finais de novembro de 1889, um concurso para encontrar a melhor melodia para um texto esboçado por Medeiros e Albuquerque. Dele participaram 36 compositores, a melodia proposta por Leopoldo Miguez tendo sido a escolhida. No entanto, o povo havia manifestado sua predileção pelo hino imperial. Pelo decreto 171 de 20 de janeiro de 1890, este antigo hino foi declarado Hino Nacional, enquanto a versão de Miguez foi declarada Hino da Proclamação da República.

Foi portanto o hino de 1831 que se tornou Hino Nacional. Joaquim Osório Duque-Estrada (1870-1927) redigiu nova letra em 1908, letra esta que foi declarada texto oficial do hino em 1922 (em 6 de setembro), por ocasião do centenário da Independência (em 7 de setembro). Este novo texto evoca "o sol da liberdade", a liberdade da nação que o "povo heroico" havia conquistado com o "grito do Ipiranga". Na parte média do texto encontra-se "pátria amada, 
idolatrada", que vela por suas crianças como uma mãe zelosa. Menciona-se também a justiça, o Cruzeiro do Sul. A bandeira, com suas estrelas e a cor verde dos louros, seria o símbolo de um amor eterno, proclamando "paz no futuro e glória no passado". Fala-se bem da bandeira no hino oficial, mas Francisco Braga e Olavo Bilac compuseram, em 1906, o hino especial em honra à Bandeira Nacional (Hino à bandeira). Com isto, coloca-se em relevo a centralidade da bandeira entre os diversos símbolos nacionais. ${ }^{23}$

\section{Uma alegoria da República?}

Ao lado dos símbolos oficiais, houve outras tentativas de simbolização política. Em um sistema monárquico, é o monarca que encarna seu país. Na República, personificações ou alegorias nacionais assumem esta função. Na França, foi a alegoria feminina da liberdade que se tornou a encarnação da nação como república-liberdade. Seu enraizamento na memória popular se manifesta pelo nome "Marianne", que é encontrado de maneira recorrente a partir de meados do século XIX. A interpretação revolucionária da figura é indicada pelo barrete frígio; a interpretação mais consensual e moderada, pela coroa, solar ou vegetal. Na França, a figura da liberdade tornou-se alegoria exclusiva da nação, justamente porque foi a República e não a Constituição, variável, que constituiu a expressão representativa da identidade nacional. ${ }^{24}$

No Brasil, também houve algumas tentativas para representar a República por uma alegoria feminina, mas em geral não foram senão pálidas imitações da figura francesa da Marianne. O exemplo mais célebre foi a "Marianne" do pintor positivista Décio Villares (o criador da bandeira republicana de 1889), uma mulher com roupas da Marianne e um barrete frígio verde. Na sala dos símbolos do antigo palácio presidencial no Rio de Janeiro (atual Museu da República), encontra-se, ao lado do quadro de Décio Villares, um busto da República com barrete frígio, obra do escultor francês Paul-Louis Loiseau Rousseau (1861-1927). Trata-se de um busto de bronze (couraça e barrete frígio) e de mármore (busto) designado oficialmente de Marianne, símbolo da República. Esta "Marianne do interior" é muito conhecida do público brasileiro, tendo para ele a qualidade de ícone republicano. ${ }^{25}$

Contudo, não houve, no Brasil, uma tradição iconográfica autônoma de uma figura que reunisse Liberdade, Nação e República. Entre os positivistas havia, é verdade, uma tradição de alegorização da mulher, mas enquanto encarnação da humanidade. Décio Villares esboçou assim, em 1890, para a Igreja Positivista, uma bandeira para as procissões com uma figura maternal 
Figura 6 - A República, de Décio Vilares, Museu da República

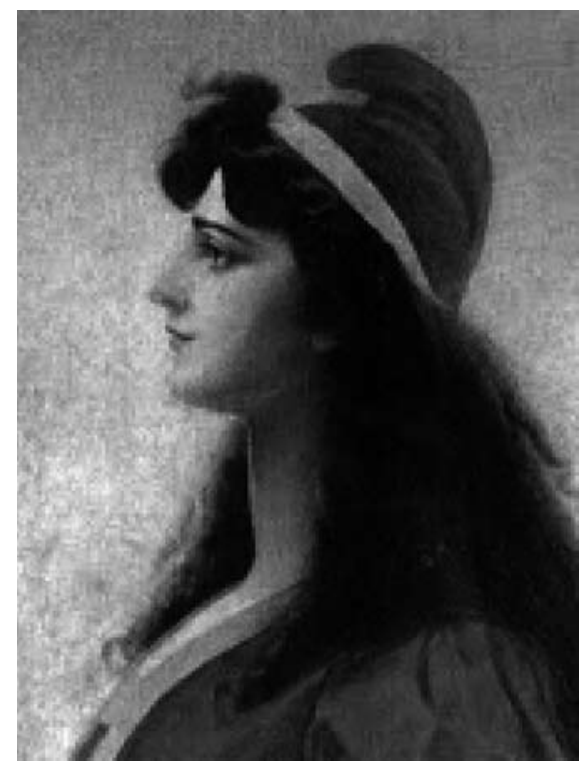

com traços da inspiradora de Comte, Clotilde de Vaux, que deveria representar a Humanidade (Carvalho 1990:77-96). Não houve no Brasil quadros tão ilustres e célebres quanto La Liberté guidant le Peuple (1831), de Delacroix, ou République (1848), de Daumier. A República como um mulher aparecia sobretudo na imprensa ilustrada, particularmente na Revista Ilustrada, por meio de gravuras sumárias e algo ingênuas. No momento da conclusão de um contrato de amizade entre o Brasil e a Argentina, foi possível ver na capa da revista, em 14 de dezembro de 1889, duas mulheres portando um barrete frígio, as bandeiras nacionais nas mãos e segurando, as duas ao mesmo tempo, uma lança coberta por um barrete frígio. No número de 21 de junho de 1890, figura uma gravura com uma jovem República brasileira olhando com admiração para a República francesa, maior, indo à frente sobre um caminho coberto de rosas. ${ }^{26}$ A República como uma mulher aparecia frequentemente nas caricaturas que exprimiam a decepção diante da nova forma do Estado, representada por alguns desenhistas como uma prostituta. ${ }^{27}$

Em 1895, o presidente da República, Prudente de Morais, encomendou ao pintor baiano Manoel Lopes Rodrigues uma imagem quase oficial da República. O pintor encontrava-se em Paris desde 1886 e contava com Jules Lefebvre como seu mestre, entre outros. Por ocasião da elaboração deste quadro, em Paris, ele se inspirou fortemente em modelos franceses, 
Figura 7 - Reconhecimento da República brasileira pela França, Revista Ilustrada, 1890

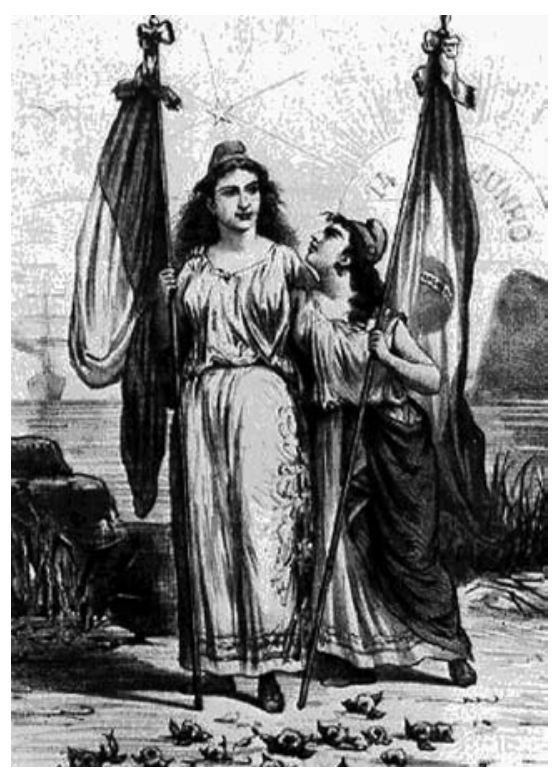

particularmente na escultura La République, de Joseph Chinard (1794), mostrando uma mulher quase hierática sentada sobre um trono que representava a estabilidade e a segurança. ${ }^{28}$

A República, de Manoel Lopes Rodrigues, também está sentada sobre um trono, vestida com um vestido branco (remetendo à paz) e se apoia sobre uma espada, pronta para dela servir-se em caso de necessidade. O barrete frígio é envolto por uma coroa de ramos de café. Com este recurso, o pintor remete à dupla tradição, francesa e brasileira, ao passo que Décio Villares tinha se contentado em vestir a Marianne tradicional de verde. Aos pés da figura, encontram-se palmas da vitória. O fundo é coberto pelas armas do Brasil, e a bandeira estilizada está envolta por uma faixa onde se lê "Estados Unidos do Brasil". O trono é enfeitado com o animal simbólico dos Bragança, a serpente, sugerindo assim a ideia de que a República se instalou sobre o antigo trono monárquico. Mas o período da presidência de Prudente de Morais (1894-1898) não correspondia em nada à imagem de uma República estável e serena, sugerida pelo quadro de Rodrigues. O país foi sacudido do exterior pela queda da cotação do café e, do interior, pela revolta milenarista de Canudos, no interior da Bahia, brutalmente reprimida pelo Exército. Esta Alegoria da República não tinha impacto algum sobre o imaginário coletivo, sendo posteriormente deixada de lado no Museu local da Bahia (Pinto Jr. 2010). 
Figura 8 - A República, por Manoel Lopes Rodrigues

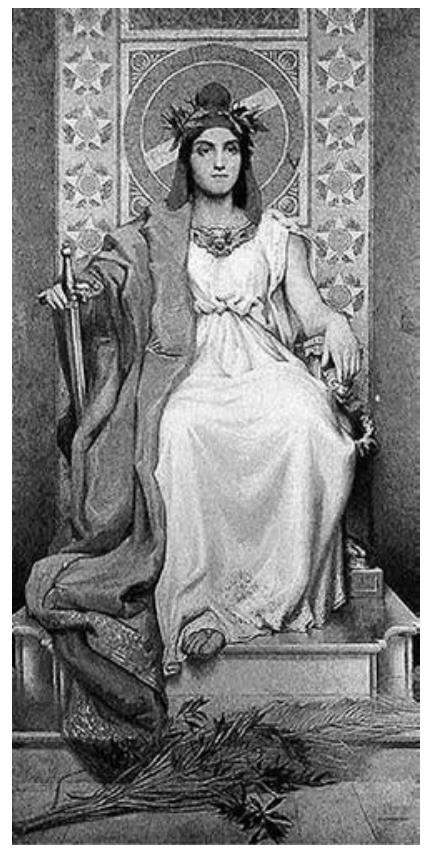

Segundo José Murilo de Carvalho, houve várias razões para que uma tradição de alegoria feminina da República não se desenvolvesse no Brasil. Por um lado, a função da mulher como símbolo foi, neste país, muito marcada pela tradição católica, já ocupada pela figura da Maria. A República impôs, de acordo com o programa de laicização dos positivistas, a separação entre Igreja e Estado; sendo assim, os meios eclesiásticos opuseram, com sucesso, a figura da Virgem àquela da República. Por outro lado, se, por ocasião da Revolução Francesa, mas também de movimentos revolucionários posteriores na França, as mulheres tinham tido um papel ativo, no Brasil, à mulher somente era atribuído um papel na vida privada, e nenhum na vida pública. Mesmo no Partido Republicano, relativamente radical, não havia membros femininos.

Para além disso, na França, tratava-se de substituir com vigor uma figura masculina forte e multissecular, aquela do Rei. A iconografia francesa da mulher como alegoria da República provém diretamente da alegoria clássica da Liberdade. No Brasil, em uma República cujo suporte mais importante era o Exército - quase todos os cargos da Administração anteriormente civil seriam ocupados por oficiais no Brasil - a Liberdade (como valor e como alegoria feminina) não podia ser propulsada ao primeiro plano, ocupado por valores mais militares de disciplina e ordem. 
Foi antes a princesa Isabel, regente do Brasil no momento em que seu pai, o imperador Pedro II, esteve ausente por razões de saúde, que pôde encarnar a realidade da liberdade. Foi sob sua regência que a Lei Áurea foi de fato promulgada, em 1888, marcando a abolição total da escravatura no Brasil. A princesa é glorificada com o título de "Isabel, a Redentora" e figurava em medalhas do movimento abolicionista, tendo em uma das mãos os grilhões rompidos e, na outra, o decreto da abolição. ${ }^{29}$ Mas os representantes da nova República não iriam promover uma figura tão importante da defunta monarquia.

\section{A invenção do herói da República: Tiradentes}

Quando da construção da identidade nacional, figuras de heróis têm frequentemente um papel não negligenciável. Na Suíça, foi a figura de Guillaume Tell; nos Estados Unidos, os founding fathers. ${ }^{30}$ Para a República do Brasil também havia "pais fundadores", os instigadores da proclamação da República, em 15 de novembro de 1889. Mas eles defendiam concepções de República muito divergentes: Deodoro da Fonseca optava por uma República militar, Benjamin Constant, por uma República "sociocrática" (seguindo a terminologia de Comte), e Quintino Bocaiuva (1830-1912), por uma República liberal. De um modo significativo, os republicanos radicais não eram representados no governo.

Benjamin Constant, o positivista mais em voga e diretor da Escola Militar, que ocuparia no novo governo o cargo de ministro da Guerra e, em seguida, da Instrução Pública, Correios e Telégrafos, foi explicitamente designado na Constituição como um dos "fundadores da República" (Bernecker et alli 2000:216). O primeiro presidente do governo provisório foi, no entanto, Deodoro da Fonseca, que não se entendia com Benjamin Constant. Deodoro da Fonseca fracassou, aliás, em sua tentativa de golpe de Estado "de cima para baixo", retirando-se da vida pública e falecendo, logo em seguida, em 1892. Benjamin Constant morreria um ano antes. Os três políticos que defendiam concepções bastante divergentes de República não estavam aptos a assumir um papel consensual de "pais fundadores" .

Foi uma figura histórica que se tornou seu substituto, através do processo clássico de "invenção da tradição" (Hobsbawm). Esta figura, que funciona como uma espécie de mito de origem, foi Joaquim José da Silva Xavier, "Tiradentes", apelido que se devia às suas atividades ocasionais como dentista, arrancando dentes. A província de Minas Gerais sofria com os impostos extremamente altos a serem pagos, ainda que a produção de 
ouro declinasse constantemente. Sob o comando de Tiradentes, atrás do qual se escondiam personalidades importantes da província, fomentou-se uma conspiração, mais tarde denominada Inconfidência Mineira (1789), que vislumbrava uma secessão da província erigida em República, com um Parlamento e Assembleias em cada cidade. É importante ressaltar, neste contexto, a importância posterior que ganhou a data "franco-brasileira" de 1789 para a construção da lenda de Tiradentes. Uma universidade seria criada em Ouro Preto. Os escravos nascidos em Minas seriam libertos. Vislumbravam-se contatos com as províncias do Rio e de São Paulo com o objetivo de criar uma confederação à imagem daquela dos Estados Unidos. Os conspiradores também reivindicavam a inspiração em pensadores do Iluminismo francês, como Diderot e Voltaire e mais ainda Mably e o abade Raynal, que havia optado pela abolição da escravatura.

Um dos conspiradores traiu e revelou todo o episódio ao governo. Tiradentes foi preso em maio de 1789. Após um longo processo, foi condenado à morte, enforcado em 21 de abril de 1792 e esquartejado. A condenação de muitos outros conspiradores foi comutada em deportação perpétua (Benassar \& Marin 2000:174-176).

A memória de Tiradentes foi revivida pelo livro de um pesquisador, Joaquim Norberto de Souza e Silva, História da conjuração mineira (1872). Este historiador enfatizava, no entanto, que o papel de Tiradentes não havia sido tão importante quanto se acreditava, e que, na prisão, seu engajamento político se transformou em engajamento religioso. Muitas personalidades republicanas constestavam, no entanto, esta tese, já que Tiradentes já havia se transformado em mito; ele era considerado um herói que tinha morrido por suas ideias, sendo apelidado de "Cristo das massa ". No Rio, havia se formado um clube Tiradentes. Após a proclamação da República, o processo de "canonização" se intensificou. Em 1890, o aniversário de sua morte, 21 de abril, foi declarado feriado.

Durante uma manifestação organizada em sua honra, em 1890, o artista positivista Décio Villares, já citado, distribuiu uma litografia de Tiradentes, representado com traços de Cristo, com uma longa barba e cabelos compridos, ornada por uma palma do mártir e por um ramo de louros. A sacralização era ainda mais evidente em um quadro de Aurelio de Figueiredo, O martírio de Tiradentes, mostrando o herói ao pé da forca sobre o cadafalso, um monge lhe estendendo um crucifixo, e o carrasco escondendo seus olhos com as duas mãos. ${ }^{31} \mathrm{Na}$ iconografia de Tiradentes, colocava-se em relevo a analogia com a história da Paixão de Cristo, bem conhecida neste país de tradições católicas, o que contribuía para o êxito da construção de Tiradentes como herói republicano (Carvalho 1990:67). À primeira vista, isto pode parecer 


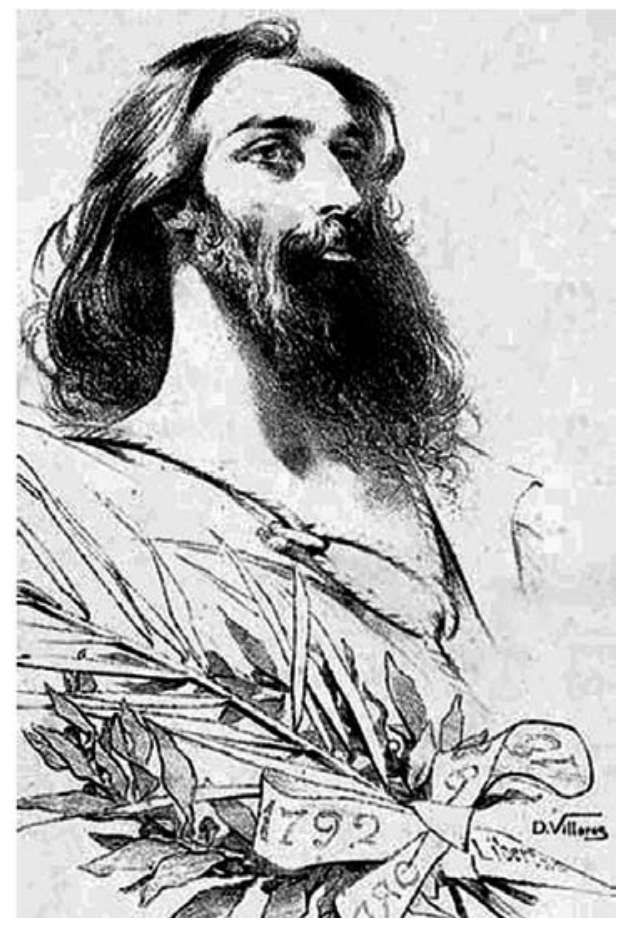

um pouco contraditório em relação ao que destacamos na análise de José Murilo de Carvalho, ao explicar o relativo insucesso da criação de uma "Marianne" brasileira, devido ao fato de a Virgem Maria já ocupar o lugar de figura feminina venerada. Mas o martírio de Tiradentes era compatível com a tradição cristã, ao passo que a figura laica da Marianne e a Virgem Maria eram incompatíveis.

A figura de Tiradentes permitia ligar vários temas: a abolição da escravatura e a criação da República, o passado e o presente. Através desse processo de sacralização, o herói deixara de ser o protagonista somente dos republicanos radicais. Mesmo os monarquistas podiam reivindicá-lo, uma vez que a monarquia havia realizado dois grandes objetivos: a independência e a abolição da escravatura. O segredo da sobrevivência do mito de Tiradentes talvez repouse, segundo José Murilo de Carvalho, em sua ambiguidade, já que a figura em relação à qual os conhecimemtos históricos permaneciam incipientes havia se tornado a tela de projeção ideal, reduzida ao mesmo tempo a uma instrumentalização bastante específica, excessivamente partidária (Carvalho 1990:73). 


\section{Balanço}

José Murilo de Carvalho constata, em seu trabalho tantas vezes citado, que os positivistas se manifestaram a propósito de quase todas as criações simbólicas que diziam respeito à República do Brasil: a bandeira, o lema, o brasão, a tentativa de criação de uma alegoria da República, o mito de Tiradentes. Segundo a concepção dos positivistas, uma pequena elite devia reconhecer as leis da evolução histórica independentemente do consentimento das maiorias populares ou parlamentares sempre versáteis. Tratava-se de agir de modo tal que o povo aceitasse ou até mesmo gostasse desta forma de governo. A fim de obter tal resultado, os positivistas se engajaram amplamente no processo de criação de símbolos da nova República, procurando ganhar por meio destas formas visuais - ou sonoras - uma população que, em sua maioria, era analfabeta (Benassar \& Marin 2000:302).

Nesta tentativa de criação de novos símbolos, a República teve, no entanto, um êxito limitado: os símbolos que se impuseram - a bandeira, os brasões e o hino - repousavam sobre a tradição imperial anterior; o mito de Tiradentes era a adaptação de uma iconografia e de uma inspiração de origem religiosa. Os símbolos não teriam criado sólidas raízes na iconografia do povo, estima José Murilo de Cravalho. A queda da monarquia se efetuou sem o concurso imediato do povo. O que foi apresentado como uma Revolução republicana foi, de fato, uma conspiração simbólica conduzida por um pequeno número de políticos idealistas e de militares pragmáticos. Foi uma "República sem povo" (Benassar \& Marin 2000:302), ainda que houvesse certamente uma aspiração mais ampla em direção a uma República como em direção à abolição da escravatura. Se a rua não se manifestou para proclamar a República, "não se precipitou tampouco em socorro à monarquia" (Enders 1997:60).

A nova Constituição, que permaneceu, no entanto, em vigor por 43 anos, definia as relações entre os três poderes. A participação do povo neles era mínima: somente poderiam votar os cidadãos masculinos com mais de 21 anos que dispusessem de certa renda e que não fossem analfabetos. Em 1894, isto representava tão somente 2,2\% da população total (Bernecker et alli 2000:217). Se, no Brasil, os símbolos da República haviam sido esboçados por uma elite política e seus artistas, tratava-se de símbolos estatais e ainda não nacionais. ${ }^{32}$ Mas devido à sua sobrevida - a da bandeira, desde 1889, a do hino, desde 1831, a do mito de Tiradentes até os nossos dias — estes símbolos tornaram-se símbolos nacionais ao lado dos símbolos "não oficiais", que são atualmente o Carnaval e o futebol.

A busca intensa por símbolos à qual se dedicara a República é uma prova da imensa importância da comunicação política. Esta política simbó- 
lica manifestou-se novamente no Brasil com a criação (voluntarista) de uma nova capital, Brasília, há apenas 50 anos, uma cidade cujo traçado desenha simultaneamente uma cruz — o Cruzeiro do Sul — e um avião ("progresso"), com a Praça dos Três Poderes em torno da qual se reúnem o Senado e a Câmara dos Deputados, o Supremo Tribunal Federal e a sede do governo. Um plano simbólico impressionante e, ao mesmo tempo, um espaço urbano perfeitamente regrado, o que não facilita a vida dos cidadãos desta cidade (demasiado simbólica). Mas esta é uma outra história...

Recebido em 08 de agosto de 2012

Aprovado em 12 de novembro de 2012

Tradução de Roberta Ceva

Joseph Jurt é professor emérito de literaturas romanas na Universidade de Freiburg, Alemanha. E-mail :<joseph.jurt@romanistik.uni-freiburg.de>

\section{Notas}

*Agradeço imensamente a Bernard Richard, não somente pela releitura minuciosa do texto, mas também por suas sugestões bastante úteis. Elas provêm em particular de Marianne en Amérique, obra em vias de elaboração, cujo manuscrito provisório me foi gentilemente cedido. Meus agradecimentos igualmente a Leopoldo Waizbort, sociólogo da USP e, particularmente, a Afrânio Garcia (EHESS), a quem devo várias observações pertinentes.

${ }^{1}$ Colóquio Internacional "Le symbolique et la formation des identités nationales européenes", Instituto Universitário de Estudos Europeus, Genebra, 3-4 maio 1991.

2 [N.T.] Chouans eram os insurgentes realistas que combatiam, ao norte do vale do Loire, em territórios a oeste da França, nas guerras civis que se sucederam à Revolução Francesa.

${ }^{3}$ Esta homogeneidade se deve, segundo o mesmo autor, à formação (uma imensa maioria oriunda de algumas instituições universitárias do Brasil que progressivamente substituem a estadia em Coimbra) e à origem social (em geral, proprietários que exercem uma profissão liberal) (Nolasco 1997:115). 
${ }^{4}$ [N.T.] O governo dos Cem Dias refere-se ao período compreendido entre 01 de março de 1815 - quando Napoleão retorna de seu exílio na ilha de Elba — e 18 de junho do mesmo ano, quando seu exército é vencido na Batalha de Waterloo. Esse período constitui a fase final das chamadas Guerras Napoleônicas, assim como do império francês de Napoleão Bonaparte.

${ }^{5}$ Sobre o reinado de Pedro II, ver também Lilia Moritz Schwarcz (1999).

${ }^{6}$ Ver Bandeira et alli (2003).

${ }^{7}$ Consultar em Bandeira et alli (2003:48-55) as imagens de várias construções (galerias e arcos do triunfo) por ocasião destas festividades.

${ }^{8}$ Vários retratos de Debret são reproduzidos no volume A Missão Francesa (:25-41). Mas Debret nos deixou, para além disso, muitas imagens "etnográficas" de pessoas (particularmente escravos) da vida cotidiana do Rio, que publicaria em uma obra de três volumes: Voyage pictoresque et historique au Brésil, ou Séjour d'un Artiste Français au Brésil (Paris 1834-1839), após seu retorno a Paris, em 1831. Ver também Xavier-Philippe Guiochon (1994).

${ }^{9} \mathrm{O}$ esboço de Debret é reproduzido no volume A Missão Francesa (:60).

${ }^{10}$ Museu Nacional do Château de Versailles, reproduzido em A Missão Francesa (:116).

${ }^{11}$ Segundo Afrânio Garcia, "o 'embranquecimento da raça' figurou como projeto intelectual, mas também como projeto político, permitindo financiar a imigração dos contingentes europeus, a começar pelos suíços [...] e, em seguida, pelos italianos. A arianização da população brasileira não foi deixada de lado no plano das ideias, mas alimentou os debates sobre os modos de se transformar a demografia da população no território. A afirmação desta hierarquia racial tinha como aposta a manutenção da elite branca, que comandava o país, mas também fixava o itinerário para que o Brasil se tornasse uma "nação civilizada", à imagem das pioneiras europeias. A cosmologia racial fundava a distribuição desigual das riquezas e os estatutos internos ao país, bem como os modos de inscrição deste país na arena internacional" (Comunicação pessoal de 12 de julho de 2012).

${ }^{12}$ Devo esta observação a Afrânio Garcia.

${ }^{13}$ Meu amigo, o sociólogo brasileiro Leopoldo Waizbort, pensa, no entanto, que sempre houve um fosso entre a população e o Exército. Seria sobretudo a população citadina (particularmente no Rio de Janeiro) que se identificaria com esta corporação (Comunicação pessoal, 08/04/2012).

${ }^{14}$ Observação de Afrânio Garcia.

${ }^{15} \mathrm{O}$ quadro é reproduzido na obra As barbas do imperador, de Lilia Moritz Schwarcz (1999). 
${ }^{16}$ Ver Richard (2012). Em relação ao caráter universal da Marselhesa, ver também o testemunho de Jean Samuel, segundo o qual os presos cantaram em primeiro lugar a Marselhesa no momento da liberação do campo de Buchenwald: "Eu pensava estar sonhando ao escutar a Marselhesa, cantada a plenos pulmões de um lado a outro, em seguida a Internacional, os hinos belga, polonês, tcheco [...]" (Dreyfus \& Dreyfus 2007:68).

${ }^{17}$ Comte prossegue afirmando que o primeiro slogan "deve ser preferido pelos homens, o segundo convém somente às mulheres, que poderão desse modo participar dignamente de nossas manifestações sociais". Mais adiante, Comte concebeu a "transição orgânica" em duas fases, caracterizadas pelos dois slogans: "Adotando a fórmula Ordem e Progresso, a primeira fase caracteriza a resolução decisiva de terminar a revolução moderna pela conciliação radical unanimemente demandada desde a explosão da crise final. A segunda manifesta com maior intensidade a verdadeira natureza da regeneração ocidental, ao proclamar a fonte moral de uma solução como esta, de acordo com uma adesão solene à lei Viver para o outro" (1854:422). Ver também Wolf 1997.

${ }^{18}$ Para certa elite brasileira, a ciência tornou-se o valor-chave, devendo contribuir para a modernização e para a industrialização do país (ver Faoro 1994:102-108).

${ }^{19}$ Sobre os vínculos entre o positivismo e a (Terceira) República francesa, ver também Nicolet (1982:249-280).

${ }^{20} \mathrm{O}$ Brasil tornou-se, portanto, um Estado federal com 20 estados; as antigas províncias obtinham novas competências. A Constituição promulgava a separação dos poderes entre uma Alta Corte de Justiça, o Senado e o Presidente. Não havia mais aquele "quarto poder" atribuído ao imperador na Constituição anterior. Na prática, o Exército intervinha por várias vezes como "poder moderador" (ver Bernecker et alli 2000:216).

${ }^{21}$ Quanto ao uso da palavra "ordem", Afrânio Garcia se pergunta se este termo não denotaria sobretudo a manutenção da antiga hierarquia fundada na escravidão, ou se remeteria a uma transição sem "igualdade real" de condição social entre descendentes de senhores e descendentes de escravos (o que será verbalizado nos anos 1930 por Freyre como recriação da dualidade "casa do senhor - casebre do escravo") (Comunicação pessoal de 12 de julho de 2012).

${ }^{22}$ Informação que devemos a Bernard Richard.

${ }^{23}$ Os quatro hinos foram reunidos no CD Hinário nacional (Manaus, Festa Irineu Garcia).

${ }^{24}$ Ver Richard (2012:77-124).

${ }^{25}$ Segundo Bernard Richard em Marianne en Amerique (no prelo:28). A respeito das estátuas da República nas províncias do Brasil, ver pp. 28-29. "No que concer- 
ne à presença da alegoria feminina da República no Brasil, na arte cívica pública, pesquisas estão em curso e outras devem ser levadas a cabo no plano local. O artigo recente de José Francisco Alves (2010) apresenta, por exemplo, as sete estátuas da República erigidas em diferentes locais de Porto Alegre (Rio Grande do Sul), entre 1889 e 1923. Por outro lado, o trabalho já citado de Richard - Marianne en Amerique (ver nota ${ }^{*}$ ) - remete ao conjunto da América Latina e compara, em particular, as situações brasileira e argentina. Tudo isto poderá nos levar a modificar posteriormente - e parcialmente - nossa abordagem da alegoria da República no Brasil" (Comunicação pessoal de Bernard Richard, 27 de abril de 2012).

${ }^{26}$ Reproduzido em Schwarz (1999:476-477).

${ }^{27}$ Bernard Richard lembra que este uso existe também na França, nos meios antirrepublicanos que mencionam a "prostituta" ou a gueuse [que também significa "mendiga", "vagabunda"], expressão criada, ao que parece, em meados do século XIX, pelo general Changarnier, que se tornou deputado "realista" (Richard 2012:108).

${ }^{28}$ Ver Marie-Louise von Plessen (1996:23).

${ }^{29}$ Reproduzido em Schwarcz (1999:58).

${ }^{30}$ Sobre os "pais fundadores" nos Estados Unidos, ver Bernard Richard, Marianne en Amerique (:7).

${ }^{31}$ Quadro reproduzido em Schwarcz (1999:473).

${ }^{32}$ Ver Rosa Ribeiro (2006:6).

\section{Referências bibliográficas}

AGULHON, Maurice (ed.). 1973. 1848 ou l'apprentissage de la République 1848-1852. Paris: Seuil. 1979. Les quarante-huitards. Paris: Gallimard.

ALENCASTRO, Luiz Felipe de. 2006. "Le versant brésilien de l'AtlantiqueSud: 1550-1850". Annales HSS, 2: 339-381.

ALVES, José Francisco. 2010. "Marianne em Porto Alegre: a alegoria da Re- pública ao ar livre (1899-1923)". In: Actas del $1^{\text {er }}$ Seminario Internacional de Arte Público en Latinoamérica. Buenos Aires: GEAP. CDRom.

BACZKO, Bronislaw. 1992. "Mythes et représentations de la Révolution Française". In: Renzo Zorzi (ed.), L'eredità dell'ottantanove e l'Italia. Firenze: Olschki.

BANDEIRA, Júlio; XEXEO, Pedro Martins Caldas \& CONDURO, Roberto. 2003. 
A Missão Francesa. Rio de Janeiro: GMT Editores.

BENNASSAR, Bartolomé \& MARIN, Richard. 2000. Histoire du Brésil 15002000. Paris: Fayard.

BERNECKER, Walther L.; PIETSCHMANN, Horst \& ZOLLER, Rüdiger. 2000. Eine kleine Geschichte Brasiliens. Frankfurt: Suhrkamp.

BRUNO, Eduardo. 2003. Brasil: uma história. São Paulo: Ática.

CAPITANI, François de. 1991. "L'ancienne confédération helvétique". In: D. Gamboni \& G. Germann (eds.), Emblèmes de la liberté. L'image de la République dans l'art du XVIe au XXe siècle. Berne: Stämpfli. pp. 124-127.

CARVALHO, José Murilo de. 1990. A formação das almas: o imaginário da República no Brasil. São Paulo: Cia. das Letras. COMTE, Auguste. 1851. Système de politique positive ou traité de sociologie, instituant la religion de l'humanité. T. I. Paris: A la Librairie ScientifiqueIndustrielle de L. Mathias.

• 1854. Système de politique positive. T. IV. Paris: A la Librairie ScientifiqueIndustrielle de L. Mathias.

COSTA, Wilma Peres da. 1996. A espada de Dâmocles: o exército, a Guerra do Paraguai e a crise do Império. São Paulo: Hucitec.

ENDERS, Armelle. 1997. Histoire du Brésil contemporain XIXe-XXe siècles. Bruxelles: Editions Complexe.

FAORO, Raymundo. 1994. Existe um pensamento político brasileiro? São Paulo: Editora Ática.

FEHRENBACH, Elisabeth. 1971. “Über die Bedeutung der politischen Symbole im Nationalstaat". Historische Zeitschrift, 213:296-355.

GAUCHET, Marcel. 1981. "Les deux corps du roi au pouvoir sans corps. Christianisme et politique". Le Débat, 14: 133-157.
GIRARDET, Raoul. 1984. "Les trois couleurs". In: P. Nora (ed.), Les lieux de mémoire I: La République. Paris: Gallimard.

GUIOCHON, Xavier-Philippe. 1994. "Le Brésil face au regard artistique français: Debret et la Mission Artistique de 1816". Cahiers du Brésil Contemporain, 23-24:39-58.

HATTENHAUER, Hans. 1984. Deutsche Nationalsymbole. Zeichen und Bedeutung. Munich-Vienne: Olzog.

JURT, Joseph. 1993. "La nouvelle Allemagne: quels symboles?". Actes de la Recherche en Sciences Sociales, 98: 45-58.

1999. "Die Rolle der Nationalsymbole in Deutschland und Frankreich". In: J. Jurt; G. Krumeich \& T. Würtenberger (eds.), Wandel von Recht und Rechtsbewusstsein in Frankreich und Deutschland. Berlin: Berlin Verlag Arno Spitz. pp. 67-90.

_. 2000. "Symbolische Repräsentation nationaler Identität in Frankreich und Deutschland nach 1789". In: Ruth Florack (ed.), Nation als Stereotyp. Fremdwahrnehmung in deutscher und französischer Literatur. Tübingen: Niemeyer. pp. 115-140.

KANTOROWICZ, Ernst H. 1957. The king's two bodies: a study in mediaeval political theology. Princeton: Princeton University Press [Tradução alemã. 1992. Die zwei Körper des Königs. Eine Studie zur politischen Theologie des Mittelalters. Stuttgart: Klett-Cotta].

NICOLET, Claude. 1982. "Idéalisme, positivisme et république". In: L'idée républicaine en France (1789-1924). Essai d'histoire critique. Paris: Gallimard. pp. 249-280.

NICOUliN, Martin. 1996. Aventures des suisses à Nova Friburgo. Fribourg: Bibliothèque Cantonale et Universitaire. 
1973. La genèse de Nova Friburgo. Emigration et colonisation suisse au Brésil 1817-1827. Fribourg: Editions Universitaires [Tradução brasileira. 1996. A gênese de Nova Friburgo. Emigração suíça no Brasil (1817-1827). Nova Friburgo: Prefeitura Municipal de Nova Friburgo].

NOLASCO, Patricio. 1997. "L'état de l'Etat-nation. Une approche de la question brésilienne", Lusotopie, 107-123. Paris: Karthala.

PAQUETTE Daniel. 1992. "La Marseillaise: ascendance et descendance". Le Jura Français, 216:243-249.

PAUL, Gerhard. 1990. Aufstand der Bilder. Die NS-Propaganda vor 1933. Bonn: J.H.W. Dietz.

PAUL, Wolf. 1997. "Ordem e progresso. Entstehung und Deutung des brasilianischen Fahnensymbols". In: Heinz-Dieter Assmann et alii (eds.), Wirtschaftsrecht und Medienrecht in der offenen Demokratie. Freundesgabe für Friedrich Kübler zum 65. Geburtstag. Heidelberg: C.F. Müller. pp. 111-128.

PINTO JR., Rafael Alves. 2010. “Manoel Lopes Rodrigues e a Alegoria da República (1896): do cotidiano da política à imortalidade do Panteão". Rio de Janeiro, V (4). Disponível em: $<$ http://www.dezenovevinte.net/obras/ mlr_rapj.htm >.

REICHEL, Peter. 2005. Schwarz-rot-gold. Kleine Geschichte deutscher Nationalsymbole nach 1945. Munich: Beck. RIBEIRO, Renilson Rosa. 2006. “República(s) imaginada(s)". Revista Aulas, 2:1-8. RICHARD, Bernard. 2012. Les emblèmes de la République. Paris: CNRS Éditions. - Marianne en Amérique [no prelo]. RUMPF, Eckhard. 2004. Unterentwicklung der politischen Parteien und Dominanz der Eliten in Brasilien. Tese de doutorado, Universidade de Berlim.
SAMUEL, Jean \& DREYFUS, Jean-Marc. 2007. Il m'appelait Pikolo. Un compagnon de Primo Levi raconte. Paris: Robert Laffont.

SCHWARCZ, Lilia Moritz. 1999. As barbas do imperador. D. Pedro II, um monarca nos trópicos. São Paulo: Companhia das Letras.

THIESSE, Anne-Marie. 1999. La création des identités nationales. Europe XVIII ${ }^{e}$-XX ${ }^{e}$ siècle. Paris: Seuil.

VON PLESSEN, Marie-Louise (ed.). 1996. Marianne und Germania 1789-1889. Berlim: Argon.

VOVELLE, Michel. 1984. "La Marseillaise. La guerre ou la paix". In: P. Nora (ed.), Les lieux de mémoire. T. I: La République. Paris: Gallimard. 
Resumo

Os símbolos da República, constituída no Brasil em 1889, não indicam uma ruptura radical com o regime monárquico anterior, como foi o caso na França. As cores da bandeira imperial remetiam às cores dinásticas. Na República, sua estrutura foi mantida, sendo acrescentado o lema "Ordem e Progresso", o que atestava que os positivistas haviam conseguido impor sua interpretação do novo regime. Quanto ao Hino Nacional, a República não havia conseguido infundir uma nova versão, o povo tendo manifestado sua predileção pelo hino imperial. Quanto à alegoria da República, havia tentativas de representá-la por figuras femininas, demasiado próximas, no entanto, da Marianne francesa. A figura de Tiradentes tinha uma ressonância mais durável, porque permitia ligar várias dimensões da nação: a abolição da escravatura e a independência.

Palavras-chave Identidade nacional, Símbolos nacionais (França, Alemanha, Brasil), Nacionalismo de Estado, Alegoria da Républica, Tiradentes.

\section{Abstract}

The symbols of the Republic established in Brazil in 1889 do not indicate a radical break with the previous monarchical regime, as was the case in France. The imperial flag's colors refer to those of the Bragança dynasty. The Republic maintained the flag's structure, but added the motto "Order and Progress", which attested to the fact that the positivists had managed to impose their interpretations upon the new regime. As for the national anthem, the Republic failed to choose a new one and the people manifested their preference for the old imperial anthem. As for the allegory of the Republic, there were attempts to represent it with female figures which were, however, too similar to the French Marianne. The figure of Tiradentes had a resonance that was more durable because it permitted the intercnnection of two primary dimensions of the nation: the abolition of slavery and independence.

Key words National identity, National symbols (France, Germany, Brazil), State nationalism, The Alegory of the Republic, Tiradents. 